\title{
ON THE AGGLUTINATION OF BACTERIA.
}

\author{
By GRoRGES DREYER, M.D., and A. J. JEX-BLAKE, Radcliffe \\ Travelling Fellow of the University of Oxford.
}

Fron the University Laboratory for Medical Bacteriology, Copenhagen.

\section{INTRODUCTION.}

Sivce Nicolle drew attention to the fact that the agglutination of bacteria by an agglutinating immune serum depended upon the formation of a compound between the agglutinating body, or agglutinin, of the serum and the agglutinable substance in the bacteria, and after Bordet and later Joos had proved that this agglutination would not take place unless a salt were present, it has been customary to regard the process as a direct or indirect consequence of the union of these three substances. Very various views, however, are held by different observers as to the precise nature of this union. Thus Gruber and Neufeld believe that it is a simple chemical combination; Joos, that it resembles the formation of a double salt; while Bordet states that the union is no more than a simple physical process of absorption, and that it brings about agglutination either directly or in consequence of a change in the molecular attraction between the bacteria and the Huid in which they are suspended.

The application of Ehrlich's side-chain theory and its terminology to the phenomena of agglutination has led to still further speculation as to the nature and mode of action of the specific agglutinins, that is to say, of those occurring in immune sera. Ehrlich, Wassermann, and Kirstein regard agglutinins as receptors of the second order; Bail believes them to be receptors of the third order. Eisenberg and Volk appear to be uncertain whether they are receptors of the second order or of the third, and describe the agglutinins as composed of two molecular groups, the first a labile specific group causing agglutination, the second a more stable group that serves to unite the agglutinin to the bacteria that are to be agglutinated. Proceeding further, they state that an agglutinin can be converted partially or entirely into an agglutinoid by various physical or chemical agents, such as heat, acids, or alkalies; and they compare the agglutinoids to Ehrlich's toxoids. The discoveries of Eisenberg and Volk, Wassermann, and others, go to show that the agglutinoids fall into two classes, the proagglutinoids and the synagglutinoids; the former having an affinity greater than, 1-JL. OF PATB. - VOL. XI. 
the latter an affinity equal to, that of the agglutinin for the agglutinable substance of the bacteria; while neither of them is able to bring about agglutination by its own unaided action, yet their presence in solution hinders agglutination by an agglutinin, since they unite with the binding groups of the bacteria, and thus prevent the agglutinin from doing so.

In the same way they suppose that there exist in the bacteria a group that is but little resistant, the agglutinophore, and a second more stable group with which the agglutinin unites, i.e. Ehrlich's haptophore group.

Our own researches have been made with the special object of ascertaining the precise nature of the changes produced both in the agglutinating immune serum and in the bacteria by the action of various physical and chemical agents upon them, and of clearing up a few of the questions to which the numerous investigations into the nature of bacterial agglutination published during the last few years have given rise.

\section{Experimental Methods.}

Most of the following experiments were made with growths from a stock culture of Bacillus coli communis on the one hand, and with the agglutinating immune serum derived from goats or rabbits after they had been immunised by injections of this race of bacteria on the other; this is the serum and these are the bacteria employed throughout the following experiments wherever no special statement is made to the contrary effect. Additional experiments were made in certain cases with $B$.typhosus and the corresponding typhosus-agglutinating immune serum.

Following earlier observers, we have usually employed an agar or bouillon culture twenty-four hours old; the age is specially mentioned where this is not the case. In the great majority of our experiments agar cultures were employed, for two reasons: first, because we wished our experiments to correspond as closely as possible to those of the various writers already mentioned; and secondly, because emulsions of the bacteria grown upon agar are free from the presence of the numerous unknown chemical substances contained in the bouillon cultures, and are therefore more likely to give precise and uniform results.

On the one hand, the use of bouillon cultures is not without its advantages; such cultures are easily prepared, and expose the bacteria to the action of the agglutinin with the least possible disturbance of the natural conditions under which they have been grown.

On the other hand, there are two great objections to the use of bouillon cultures: one is the presence of many unknown substances in them, as has been already stated; the other is the fact that one has no exact control over the number (or concentration) of the bacteria in 
such cultures, for different 24-hour growths may show considerable variations in this respect. Finally, the very general tendency of bouillon cultures of $B$. coli communis to spontaneous agglutination must be mentioned, a phenomenon recorded by a large number of experimenters, and one upon which too much stress has often been laid.

The bacteria used in the preparation of the emulsions or suspensions were grown at $37^{\circ}$ on the surface of ordinary meat-peptone agar in large Roux's bottles; the growth was carefully scraped off in as dry a state as possible, and emulsified very thoroughly in 0.85 per cent. $\mathrm{NaCl}$ solution, which will be subsequently referred to as normal saline. The agar-culture suspension thus obtained was standardised to a definite degree of opalescence or opacity (i.e. $\frac{1}{1}$ normal emulsion), by diluting it with normal saline until it presented the same degree of opacity as a certain standard emulsion of arbitrarily chosen strength, to which formaldehyde had been added as a preservative; the comparison and standardisation were effected by the observation of lines ruled on paper through two small test tubes filled, one with the standard, and the other with the new enulsion, and held side by side. The employment of some such standard emulsion as the starting-point for all subsequent experiments is of the greatest importance, and is really an absolute necessity for exact work.

It is well known that the agglutinating power of an immune serum may vary more than 100 per cent., according as the measurements are made with a denser or a thinner bacterial emulsion (Sacquépée), and other allied phenomena, such as the combining proportions, the "zones of inhibited agglutination," and so onexhibit similar wide variations. Eisenberg and Volk have endeavoured to avoid this source of error by making up the bacteria grown in a given time on a definite area of agar surface to a definite volume of bacterial emulsion; but the nature of bacterial growth renders such a method of procedure obviously inadequate, and our own experiments have shown us that emulsions of bacteria made up in this manner may vary from one another more than 100 per cent. in bacterial concentration. A fresh emulsion in normal saline of a 24-hour agar culture of our $B$. coli was always acid in reaction; titrated against $\mathrm{NaOH}$ solution, and using phenolphthalein as indicator, its acidity was equivalent to that of an equal volume of $\frac{1}{10000}$ to $\frac{1}{20000}$ normal $\mathrm{HCl}$ solution.

The agglutinating immune sera, derived from goats or rabbits, were kept constantly on ice and in darkness ; in some cases with the addition of small amounts of chloroform as an antiseptic, in other cases without it. We would here emphasise the fact that we bave never been able to observe any irregularities in our experiments that could be attributed to the addition of these small amounts of chloroform to the sera.

The general technique of the experiments was as follows:-Small 
test tubes, measuring $1 \cdot 1 \mathrm{~cm}$. by $7 \mathrm{cms}$. were set up in series, and into each tube were measured 1.5 c.c. agar-culture suspension ${ }^{1}$ or bouillon culture, together with such an amount of sterile normal saline as would make the total amount of fluid in each tube 2.5 c.c. after the due addition of the agglutinating fluid - whether serum or acid-had been made. Each series contained twenty-four, thirty-five, or fiftyseven test tubes in the different experiments, and the amount of agglutinating substance put into each successive tube diminished regularly from one end of the series (tube No. 1) to the other. Each test tube therefore contained the same quantity of bacterial suspension, and the strength of the emulsion was the same in every tube; but the amount of agglutinating substance added to each was, roughly, four-fifths of that added to the tube immediately preceding it in the series, and proportionately greater than the amount placed in the tube following next to it. Thus tube No. 1 contained ten times as much agglutinating substance as tube No. 12, and No. 12 again contained ten times as much as tube No. 23 ; in the long series of 57 test tubes, No. 1 would contain 100,000 times as much agglutinating substance as No. 56. The last tube in every series was kept as a control, containing 1.5 c.c. emulsion +1 c.c. of normal saline, and none of the agglutinating substance, thus serving to detect the possible occurrence of spontaneous agglutination. In many of the experiments the normal saline and the agglutinating substance were measured into the tubes first, the 1.5 c.c. of emulsion being added after them, so as to diminish the experimental error due to the different lengths of time during which the bacteria and the agglutinating substance, whether serum or acid, would be acting upon one another in the different tubes. The actual measurements of the amounts of agglutinating substance and normal saline placed in the tubes were made with a 1 c.c. pipette divided into 100 parts, while the emulsion was added from a 10 c.c. pipette divided into 100 parts. The diluted sera and acids were made up with normal saline, except in cases where special mention is made to the contrary effect.

In certain of the experiments, use was made of agglutinating sera that had been exposed for a longer or shorter time to the action of an acid or of an alkali; and here we found that a new source of error crept in. Taking, for example, a series of twenty-four tubes, the acidified serum added in quantities varying from 1 to 0.13 c.c. to tubes Nos. 1 to 11 would, in the ordinary course of the experiment, be further diluted by the addition of nine volumes of normal saline to it, before it was added, in quantities varying from 1 to 0.1 c.c., to Nos. 12 to 23. But it was found that a serum which had been acted

\footnotetext{
1 Whererer an agar-culture suspension of any given age is mentioned in these pages, a standardised suspension in sterile 0.85 per cent. $\mathrm{NaCl}$ solution of bacteria grown on agar at $37^{\circ}$ for the given time is meant. When the age is not mentioned, it is always to be understood that the culture is of twenty-four hours' growth, whether on agar or in bouillon.
} 
upon by an acid or an alkali would exhibit a sudden change in its properties on being thus further diluted; so that the continuity that might have been expected to appear in the results was liable to a sudden interruption between tubes 11 and 12 , at the point where the further dilution of the acidified serum had been made. This effect was no doubt due to the sudden change in the degree of dissociation of some unknown serum-acid compound formed in the acidified serum; it was completely obviated by the employment of a 0.10 c.c. pipette, divided into twenty parts, for adding the serum to tubes Nos. 12 to 23 , using, of course, the same serum as had already been added (from a 1 c.c. pipette) to tubes Nos. 1 to 11 , without further dilution.

The test tubes in each experiment were all well shaken up, so as to mix their contents thoroughly, as soon as the appropriate quantities of emulsion, normal saline, and agglutinating solution had been measured into them. They were then placed at once in an Ostwald's water bath at $37^{\circ}$ for from one and a half to two hours, when they were removed and the measurements of the agglutination that had taken place were made. When it was necessary, owing to slowing of the agglutination and protraction of the time taken by the reaction, the measurements were made a second time after the tubes had stood for a further eighteen hours at the temperature of the room.

The actual measurement of the degree of agglutination attained, one of the most important questions in researches such as these, was made by Madsen's method, which gives admirable results in cases where it can be applied. The method consists, as is well known, in the arbitrary selection of a single moderately agglutinated tube in one of the series as a standard, and then noting which tube in each of the other series is agglutinated to just the same degree by direct comparison. This can be conveniently done as a rule; but in cases where the size or the character of the flocculi of agglutinated bacteria vary in the different series of tubes, it is impossible to take the measurements by Madsen's method.

On such occasions the measurement was set down as standing at the tube containing the minimum of agglutination visible to the naked eye; it was necessary to use this method, for example, in many of the experiments upon the influence of heat on the agglutinability of bacteria.

To conclude with a brief estimate of the value of these two methods of measuring agglutinating pouer, it must be emphasised that in a considerable number of cases they lead to discordant results, giving values that differ relatively as well as absolutely; so that given a number of series of tubes, the amounts of agglutinating substance needed to produce the smallest amount of agglutination macroscopically visible will bear no constant relation to the amounts present in the tubes that show the same degree of agglutination when the measurements are inade by Madsen's method. In some of the series the two tubes will 
be close together, in others they will be at some distance from one another; in the former case containing somewhat similar amounts of agglutinating substances, in the latter amounts that are widely different. The explanation of these discrepancies we are unable to give; they appear to depend upon a variety of conditions that will not be further particularised. Which of the two measurements is to be accepted as the correct one is really a matter of opinion; but care must be exercised in accepting as final the results that may be deduced from the application of either of them alone, without reference to the other.

The results of the experiments depend not only upon the method of measurement adopted, but also upon the length of time that elapses before they are made. Where the agglutinating power of a series of simple immune sera is being measured, and unheated agar-culture suspensions or bouillon cultures are employed, the measurements obtained after the tubes have been kept for one and a half to two hours at $37^{\circ}$ are practically identical with those taken after they have stood for a further eighteen hours at the temperature of the room.

But these two readings lead to totally different results when either the immune serum or the bacterial suspension or both have been exposed, before mixing, to the action of heat or of an acid or an alkali. Under such circumstances it is possible for the measurements taken after from one and a half to two hours to show that practically all of the agglutinin in the immune serum has been destroyed, while eighteen hours later it may be evident that almost all of this destruction has been apparent rather than real.

In other words, the velocity with which the chemical reaction or the physical change upon which bacterial agglutination depends is a very variable factor, and one of the greatest importance for the final result.

Further researches have also shown us that in many cases the agglutinating values given by the use of heated bacterial suspensions in no way correspond with those obtained from suspensions that have not been heated; in just the same way many of the experiments detailed below show that the values obtained with agar-culture emulsions differ widely from those obtained with bouillon cultures. These facts and relations are again of the greatest importance for the proper understanding of the phenomena of agglutination, and have been unduly neglected, speaking generally, by earlier investigators.

Having discussed the methods of measurement, we must lay particular emphasis upon the fact that under certain various conditions, when for example either the bacterial suspension or the immune serum bas been exposed to the action of chemical or physical forces, whether of known or of unknown nature, the degree of agglutination observed may be a quite unreliable index of the amount of agglutinating substance present. 
Passing next to the results of our own experiments, it must first be mentioned that the letters used at the heads of the columns in the different Tables given at the end of the paper have the following meanings :-

A.A. The absolute amounts of the agglutinating serum, measured in c.c., necessary to produce a degree of agglutination equal to that present in the tube selected as standard.

R.A. The relative amounts of agglutinating serum necessary to produce the given degree of agglutination. The absolute amount of serum which is here taken as unity is given immediately under the letters themselves, in c.c.

The culture-B. coli for example-mentioned at the head of the several columns is the culture used in that vertical series of experiments; the agglutinating serum used is the corresponding one-a $B$. coli immune serum in the above case-in every instance.

\section{The Age of the Bacterial Culture.}

The length of time for which the culture has grown in the incubator at $37^{\circ}$ has considerable influence upon the results obtrined when it is agglutinated. Bossaert was the first to concern himself with the influence of its age upon the agglutinability of the bacterial culture. Our own researches show that the age of the culture is of the greatest importance when a bouillon criture is used, but that it has comparatively little influence upon the agglutinability of agarculture suspensions. Thus the figures given in Table I., Series 1 to 5 , show that the suspensions made from agar cultures of different ages are more or less equally agglutinable (see Series 1, column R.A.), while bouillon cultures become very considerably less so as they grow older; for example, a 12-day bouillon growth may be only one-sixteenth as agglutinable as a 24-hour culture (see Series 3, column R.A.), the former requiring sixteen times as much serum to produce a given degree of agglutination as the latter. This diminution in agglutinability seems to be mainly if not exclusively due to the development, during the growth of the bacteria in the bouillon, of certain substances (the "toxin") which can unite with the agglutinin of the serum and so prevent it from uniting with the agglutinable substance of the bacteria; when large quantities of agglutinin are present, the "toxin" can be precipitated. That substances with the above properties are formed in old cultures of $B$. coli communis and B. typhosus was first observed by Kraus in 1897 , and they have been described since then by Radzievsky, Wassermann, and others.

The proportions in which the bacterial toxin and the agglutinin of the irmmune serum combine together, on the other hand, have not yet, to the best of our knowledge, been subjected to investigation.

It is quite otherwise with the combinations between bacteria and 
agglutinins, since these have been the objects of the very extensive and illuminating investigations of Eisenberg and Volk. These authors have shown that if increasing quantities of an agglutinin are added to a constant amount of bacterial emulsion, the absolute absorption of agglutinin increases while the coefficient of absorption-that is to say, the relation between the quantity of agglutinin that is absorbed and the quantity that was originally present-diminishes. The figures given by Eisenberg and Volk have been made use of by Arrhenius, who finds that the relation between the agglutinin and the combining substance of the bacteria can be expressed by the formula-

$$
\mathrm{C}=\mathrm{KB}^{\mathrm{a}}
$$

where $\mathrm{C}=$ the quantity of combined agglutinin, $\mathrm{K}=\mathrm{a}$ constant, $\mathrm{B}=$ the quantity of free agglutinin.

Without entering more closely into the quantitative relations of the compounds formed by the agglutinins and their nature, we may state that we have found that the agglutinin combines with the $B$. coli "toxin" in quite different proportions.

Omitting the details of these experiments, we may mention that the $B$. coli "toxin" employed was the bacterium-free filtrate of a $B$. coli bouillon culture kept at $37^{\circ}$ for nineteen days. In the experiments we made the amount of this " toxin" was kept constant, the quantity of immune serum agglutinin exposed to its powers of absorption being varied. It was found that with increasing amounts of agglutinin its absolute absorption increased, while the coefficient of absorption-that is to say, the ratio of the quantity of agglutinin absorbed to the quantity originally present-remained practically unaltered within the limits of our experiments. The change in magnitude of the coefficient of absorption was, speaking generally, of such a nature that its value slowly diminished as the quantity of agglutinin exposed to its action grew less. This result is just the opposite of that found by Fisenberg and Volk in the case of the bacteria, so that the formula $\frac{\mathrm{C}}{\mathrm{B}^{\frac{3}{3}}}=\mathrm{K}$ calculated by Arrhenius on the basis of their figures does not hold good for the combining ratios of the $B$. coli "toxin" and the agglutinin. To what extent these facts may modify the present views of the laws that regulate the combinations of agglutinin with the combining substance of the bacteria, is being made the subject of further investigation.

\section{The Efrect of Heat on the Bacterial Emulsion.}

The diminished agglutinability of bacterial emulsions or suspensions that have been heated has been noted by many experimenters. But the temperature at which this change is first observed and the degree 
to which it proceeds have been very differently recorded by the various authors, and they are far from unanimous in their explanations of the phenomenon.

Van de Velde, for example, found that the agglutinability of his strain of $B$. typhosus was not diminished when the suspension was heated to $60^{\circ}$ for half an hour, but that it fell to $\frac{1}{60}$ of its original value when the suspension was heated to $65^{\circ}$ or $70^{\circ}$ for a similar period. Nicolle states that in many cases $B$. typhosus becomes inagglutinable after it has been heated to $115^{\circ}$ for twenty minutes, while $B$. coli communis loses little of its agglutinability at temperatures below $90^{\circ}$, and does not lose it all even at $140^{\circ}$.

Our own experiments (see Tables II. to XI., Series 6 to 52) were conducted partly with agar cultures of various ages suspended in normal saline, and partly with bouillon cultures, and were designed to illustrate the change in the agglutinability of $B$. coli produced by heat; experiments were also made with $B$. typhosus for purposes of comparison. The object was to arrive at figures which would express numerically the diminution in agglutinability caused by heating the suspension for a given time to temperatures varying from $40^{\circ}$ to $100^{\circ}$, and also to find the diminution in agglutinability consequent on heating the suspension to a given temperature, to $70^{\circ}$ or $100^{\circ}$ for example, for longer or shorter periods. For all temperatures under $100^{\circ}$ the heating was done in a water bath, which was gradually raised to the required temperature and then kept at that temperature as long as was necessary. At $100^{\circ}$ the heating was done in a Koch's steam steriliser. All the experiments of any particular series were carried out at the same time on the same day, so that the values found in each series are directly comparable inter se. Every care was taken to prevent any variation in the conditions of the successive experiments from one day to another, or in the details of the heating of the bacterial suspensions or agglutinating sera. It should be noted that when either a $B$. coli suspension in normal saline, or a bouillon culture of it, is heated to $100^{\circ}$ for even fifteen minutes, it becomes less opaque. The longer this heating is continued the greater is the loss in opalescence, so that after six hours at $100^{\circ}$ the suspension is only half as opaque as it was at first. Hence it seems to be best under these circumstances to subject a strong suspension of the bacteria to the heating, and to dilute it to the standard opalescence afterwards, when the effect of prolonged heating upon the bacteria is being examined.

It appears from these experiments that temperatures below $60^{\circ}$ diminish the agglutinability of the cultures but little, while heating them to from $75^{\circ}$ to $100^{\circ}$ diminishes it very considerably. In most cases the loss of agglutinability is comparatively small at $70^{\circ}$, the heated suspension requiring only two or three times as much agglutinin to produce a given degree of agglutination, as is needed by the 
unheated culture; but at $80^{\circ}$ there is a sudden and considerable loss of agglutinability, which falls to one-tenth or one-twenty-fifth of its original value. Hence the agglutinability does not diminish regularly as the temperature rises; it diminishes further, but not so rapidly, as the temperature increases from $80^{\circ}$ to $100^{\circ}$. In spite of all endeavours to obtain uniformity in all the details and in the conditions of the experiments, it is at once obvious that the results of the different series show very considerable variations, and in spite of the fact that the same agglutinating serum was nsed in all the experiments of Series 6 to 29 . Yet we are unable to explain how it is that a 24-hour agar culture of our $B$. coli can give such widely varying results, from one day to another, when its suspensions are exposed to heat and then agglutinated-see Series 6 to 1.5, unless it be the case (as was suggested on a previous page) that the discrepancies are more apparent than real, and depend upon the inherent deficiencies of the methods of measuring agglutinating power; at any rate they appear not to depend upon differences in the reaction of the suspensions used. It is to be noted that the longer an agar culture has remained at $37^{\circ}$ the less is its agglutinability impaired by the action of heat, as the figures of Series 22 to 27 clearly show; and also that the first subcultures taken from a tube of $B$. coli that had been kept at the temperature of the room for six weeks were comparatively little influenced by exposure to heat. But this increased resistance to heat soon disappeared from the successive subcultures made at short intervals from the original tube. If the influence of temperatures between $40^{\circ}$ and $100^{\circ}$ upon agar cultures and bouillon cultures of $B$. coli be more narrowly examined, it will be seen that there is an obvious difference in the behaviour of the two; the bouillon cultures -see Series 28 and 29 -do not give more uniform results, but illustrate the fact that agglutination can occur in different ways. When an agar-culture suspension has been heated to temperatures between $40^{\circ}$ and $100^{\circ}$, it often exhibits irregular agglutination and a zone where agglutination has been inhibited, as is shown by the fact that large amounts of the immune serum produce a less degree of agglutination than smaller amounts do; this is exhibited in Series 10 to 14,16 and 17, and 35 and 36. At the same time, one frequently sees that quantities of serum that are insufficient to agglutinate the unheated suspension will produce agglutination in it when it has been heated; while, on the other hand, the agglutination produced by a small amount of agglutinin may be equal to, or even greater than, that produced by a quantity 100 times as great, as can be easily seen in the experiments of Series 35 and 36 , in which a suspension of $B$. coli was warmed to $70^{\circ}$ for various periods.

These irregularities do not occur in most instances, or, if they do occur, it is only to a small extent, when heated bouillon cultures are used; see Series 28 and 29 , and 38 to 42 . On examining these 
irregularities more closely, it is seen that they do not depend upon the degree to which the agglutinability of the bacteria is lowered. For such "zones of inhibited agglutination" are often met with in cases where the culture has only been warmed to $60^{\circ}$ or $70^{\circ}$, and are absent where it las been heated to $100^{\circ}$; but the opposite may be the case. And again, after the process of agglutination has been proceeding for two hours at $37^{\circ}$, great irregularities may be present in the degree to which it has taken place in a series of tubes; but eighteen hours later they will often have disappeared, partly-or wholly, while the tubes have been standing at the temperature of the room.

Thus there are a number of circumstances tending to prove that when agar-culture suspensions of $B$. coli are warmed, substances are formed that reduce the velocity of the reaction of agglutination; but it is doubtful whether such a condition of affairs suffices to explain the whole phenomenon.

Most of the previous workers on this subject agree in giving another explanation of this occurrence; thus Levin, working with $b$. coli, supposes that the diminished agglutinability is due to a destruction-" by the heating a great deal of the agglutinable matter in the bacteria is destroyed." Eisenberg and Volk found that B. typhosus, after heating to $100^{\circ}$, lost almost entirely its capacity for being agglutinated, while it preserved almost entirely its power of combining with the agglutinin. They explain this byoassuming that the labile agglutinophore group of the bacteria is destroyed, while the stable group that unites the agglutinin to the bacteria is far less easily injured by the action of heat. Thus they draw a close parallel between the facts here and the discoveries made by Ehrlich with reference to diphtheria toxin.

But our researches with $B$. coli go entirely against the view that the diminution of agglutinability depends upon a destruction of the agglutinable substance of the bacteria. For if it were here a question of an actual destruction or weakening, comparable to that which has been described in connection with the various bacterial toxins, it is evident that longer continuation of the heating at any given temperature could only result in a further loss of agglutinability, which would finally be complete. This however does not take place: the researches set down in Tables VIII, and IX. show that in this matter, as in others, the results obtained vary according as use is made of a bouillon culture or an agar-culture suspension.

If an agar-culture suspension of $B$. coli is warmed to $70^{\circ}$ for various lengths of time-for from one to seventy-five minutes-in certain cases (see Table VIII.) the agglutinability diminishes more and more the longer the heating is continued-see Series 33. Yet in other instances, such as Series 36 , the loss in agglutinability is practically uniform; and in yet others, continued heating even makes the suspension more easily agglutinated than it was originally-see Series 
37. But when a bouillon culture is heated, to say $70^{\circ}$, as in Table IX. Series 38 to 42 , the diminution in agglutinability is much the same whether the heating is continued for a long time or for a short.

Again, where an agar-culture suspension of $B$. coli is heated to $100^{\circ}$ for periods of from one minute to five hours-see Table X.-it appears that continued heating gradually restores the agglutinability of the bacteria, so that in some cases it finally happens that they recover their agglutinability entirely. It is not easy to understand why the same stock of $B$. coli should give such varying results at different times, when no change is made in the immune serum employed; the experiments in Series 43 to 46 were made with one serum, those in Series 47 to 50 with another.

As regards the effect of the heating of bouillon cultures to $100^{\circ}$ for different lengths of time, the figures in Series 51 show that the loss of agglutinability remains the same throughout. But if 1 per cent. of formaldehyde be added to the culture before it is warmed, then, as the experiments of Series 52 show, protracted warming causes a partial return of the agglutinability.

As an explanation of this diminished agglutinability, we believe that some portion of their contents is dissolved out of the bacteria in the process of heating their suspension in normal saline, and that some substance that unites with the agglutinin is taken up from them by the fluid in which they float.

That such a process does take place we have proved by filtering off the bacteria from the fresh suspension, both before heating and after it, and have always found that the filtrate from the heated emulsion contained substances capable of uniting with the agglutinin, while no such substance was present in the filtrate from the unheated suspension. And if fresh unheated bacteria are emulsionised in these two filtrates, it will be found that the bacteria suspended in the filtrate from the heated emulsion require considerably more immune serum for their agglutination than do the bacteria suspended in the filtrate of the nnheated emulsion.

The return of agglutinability on prolonged heating at $100^{\circ}$ may depend in part upon the slow destruction of these substances that combine with the agglutinin, or upon their conversion into substances that are indifferent to the agglutinin. That some such processes occur is shown by our experiments with the filtrate from heated $B$. coli emulsions; on further prolonged heating to $100^{\circ}$, this filtrate entirely lost its power of combining with agglutinin. But these considerations are not enough to account for the very considerable lowering of agglutinability caused by heat; some other factor which still remains obscure, possibly a change in the surface tension of the bacterial envelope, must be at work as well.

It might be urged, in opposition to the foregoing views as to the agglutination of bacteria heated for long periods, that it is wholly 
different in character from that of bacteria that have been heated for only a short time, or that have not been heated at all, and is therefore, perhaps, not a specific reaction at all. But the evidence for the specific nature of the agglutination produced by the serum is as good in the one case as it is in the other; and further, very similar phenomena have been noted by Dreyer in the case of a megatheriolysin.

This lysin, on being warmed to $60^{\circ}$ for half an hour, was found to lose its power of hæmolysing red blood corpuscles; but if the same lysin solution were then warmed to $100^{\circ}$ for ten minutes it recovered a portion-perhaps a quarter-of its original hæmolytic power. If the lysin be heated directly up to $100^{\circ}$ its power is reduced to one-sixth of what it was originally; while if it be kept at $100^{\circ}$ for ten minutes its activity partially returns, and it may be found to have half of its original power of hæmolysing red cells. Here, again, it might be argued that the megatheriolysin thus reactivated by heat is not identical with that originally present; but no such difference really exists between the two, because the specific anti-megatheriolysin is able to prevent hæmolysis by the megatheriolysin heated to $100^{\circ}$, just as it does hæmolysis by the unheated megatheriolysin.

\section{The Effect of Heat on the Agglutinating Serum.}

This question has been attacked by a number of investigators. Thus Jatta found that a serum agglutinating $B$. typhosus lost none of its power after being kept for three hours at $55^{\circ}$. Most authorsBail, Eisenberg and Volk, and others-have found that B. coli and $B$. typhosus immune sera lose a little of their agglutinating power after being kept for half an hour at $65^{\circ}$, most of it at $70^{\circ}$, and all of it at $75^{\circ}$. The use of sera heated in this way often results in the appearance of "zones of inhibited agglutination," when they are added in regularly diminishing quantities to a long series of test tubes. In other words, comparatively large amounts of the agglutinating serum fail to produce agglutination, while small quantities of it do agglutinate the bacterial emulsion.

The descriptions of this phenomenon known to us are qualitative, and do not give exact numerical details of the circumstances under which it occurs, nor do they state whether the immune serum was heated by itself, or in a condition of dilution.

Our own experiments, detailed in Tables XII. to XVIII., Series 53 to 68 , were made with three separate $B$. coli agglutinating immune sera derived from a goat. The serum in some cases was heated by itself, in othèrs after dilution with normal saline.

And here again it must be emphasised that the results obtained differ according as the measurements are made with a suspension of the bacteria grown on agar, or with a bouillon culture. The absolute as well as the relative agglutinating values are quite different in the 
two cases. Further, the results obtained depend very largely upon the time at which the measurements of the agglutination that has taken place are made, because the velocity of the reaction is often much diminished.

In consequence of this we have generally tabulated the results of measurements that were taken after various periods of time had elapsed in the several experiments; similarly, the agglutinating powers of the sera were tested on both agar-culture suspensions and bouillon cultures of the bacteria. In all cases where the experiments were thus duplicated, care was taken to perform the two sets simultaneously, and to make use of the same specimen of the diluted serum, whether heated or not. Thus these experiments are parallel and strictly comparable to one another in every possible way.

In agreement with previous workers, we have found that temperatures not above $60^{\circ}$ do not diminish the agglutinating powers of $B$. coli immune sera; no "zones of inhibited agglutination," and no other irregularities, were observed in the agglutination obtained (see Tables XII. and XIII.).

The results were the same whether the serum were heated alone or in a state of dilution.

When the serum was heated to $65^{\circ}$, differences appeared according as it was heated after dilution with normal saline or by itself alone; and when such heated sera were used to agglutinate an agar-culture suspension, "inhibition zones" appeared. For example, the experiments in Series 54 show that an agglutinating serum heated alone to $65^{\circ}$ for half an hour, when present in from 2500 to 29 times the unit quantity of the unheated serum needed to produce the definite degree of agglutination present in the test tube selected as standard may cause either no agglutination at all, or else a less degree of agglutination than that present in the standard tube; while the agglutination in the tubes containing from 28 to 2 of the agglutinating units is either total or more marked than it is in the standard tube.

But if the serum is diluted with nine volumes of normal saline before being heated, the results obtained are quite different. The tubes containing from 250 to 125 agglutinating units of serum may show no agglutination, while the tubes containing from 125 to 2 agglutinating units may be more strongly agglutinated than is the standard tube containing the single agglutinating unit of the unheated serum. So in the second of these two cases the "zone of inhibited agglutination" is less extensive than it is in the first: in one case it ends at the tube containing 125 , in the other at the tube containing 29 agglutinating units of the heated serum. Examination of the other figures obtained with sera heated to $65^{\circ}$ or $70^{\circ}$ will be found to show very similar results.

Thus the more concentrated the solution in which the immune serum is treated the more readily the "zones of inhibited agglutina- 
tion" appear. Also, inspection of the measurements recorded after the lapse of various periods of time will show that the longer the time that passes before the measurements are made, the less extensive will the "zone of inhibited agglutination" be found to be; see Series 63 and 65. In fact, a "zone" may entirely disappear if the tubes are examined a second time after they have stood for a further eighteen hours at the temperature of the room, as was the case in the experiments of Series 59 and 61.

If the agar-culture suspension of $B$. coli used for the measurements be now replaced by a bouillon culture, it is probable that no "zone of inhibited agglutination" will be found to occur, as may be observed in the figures in Series $58,60,62$, and 64 ; or if it does occur, as in Series 66 and 68 , it will only be feebly marked. The employment of sera that have been heated may also lead to the appearance of other curious phenomena in addition to the "zones of inhibited agglutination." Thus, if an agglutinating serum diluted with nine volumes of normal saline be warmed to $70^{\circ}$ for periods of thirty minutes, one hour, and two hours (see Series 65), and if the agglutinating powers of these three diluted specimens be then measured on an agar-culture suspension, it will be found that they have not diminished, but have, on the contrarys actually increased, so that their agglutinating powers are now $\frac{2}{1}, \frac{2}{1}$, and $\frac{5}{4}$, respectively, of that of the unheated serum in the same state of dilution. But if these same heated sera be tested with a bouillon culture (see Series 66), their strengths are found to be only one-half, one-half, and one-third, respectively, of that of the unheated serum. Yet in spite of this, "zones of inhibited agglutination" are a far more prominent feature with the agar-culture suspensions than they are with the bouillon cultures of $B$. coli.

Continuing with these experiments, it is seen that prolonged heating to $70^{\circ}$ causes this increased agglutinating power, seen only when agar-culture suspensions are used, to disappear again. Thus the serum diluted $1: 10$ became twice as strongly agglutinating after being heated at $70^{\circ}$ for half an hour; but after two hours at $70^{\circ}$ it was only a little stronger than it was before being heated; it must be emphasised that these measurements were made on the agar-culture suspension of $B$. coli. The experimental results detailed in Series 59 to 68 show that within certain limits the greater the dilution at which the heating is performed the greater is the reduction of the serum's agglutinating power, whether bouillon culture or agar-culture suspension be employed, - though the fact is best illustrated when the former is used. To quote an example: If the agglutinating immune serum in the three dilutions 1 in 10,1 in 100 , and 1 in 1000 be heated to $70^{\circ}$ for one hour, and the agglutinating powers of the three dilutions be then measured on a 24-hour bouillon culture of $B$. coli, they will be found to have fallen to one-half, one-fourth, and one-eighth of their original values-see Series 68 . If, on the other hand, an agar-culture 
suspension be employed, the results, as is shown by the figures in Series 67, are quite different. The agglutinating power of the 1 in 10 dilution is twice what it was before, while the 1 in 100 dilution is a little weaker (in the proportion 1 to $1 \cdot 3$ ), and the 1 in 1000 dilution has only one half of the agglutinating power it had before the heating.

It results from all these sets of experiments that the weakening of the agglutinating power of the $B$. coli serum is much more apparent when the measurements are made using bouillon culture than when an agar-culture suspension is employed.

At the present moment it is impossible to say which of the two sets of results mentioned above should be regarded as giving the more correct view of the effect of heat upon agglutinating immune sera. Further observations with other varieties of serum are needed before that question can be decided; and such experiments as are now in progress have not advanced sufficiently far to permit definite conclusions to be drawn.

The figures quoted in Series 67 and 68 further show that if the dilutions of the agglutinating immune serum be made with 1 per cent. normal horse serum instead of with normal saline, the loss of agglutinating power on heating to $70^{\circ}$ will be greater. This fact is particularly striking when bouillon culture is used in making the measurements, when also a "zone of inhibition" occurs which is, however, small in extent, and diminishes if the test tubes are allowed to stand and are observed again after the lapse of many hours.

The occurrence of these "zones of inhibited agglutination" is explained by Eisenberg and Volk as due to the conversion of a part of the agglutinin into agglutinoid by the action of heat. The agglutinoid cannot produce agglutination, but it has a stronger affinity for the agglutinable substance of the bacteria than is possessed by the agglutinin, whose action it is, in consequence, able to prevent. In confirmation of this view, they bring forward the statement that the greater the destruction of the agglutinin the more pronounced is the "inhibition zone." But this explanation is inapplicable to the results of our experiments, which prove clearly that the actual destruction of the agglutinin does not depend upon or stand in any definite relation to the extent of the "zones of inhibited agglutination." The agglutinating power of a serum can be much weakened while the "inhibition zone " is but ill-marked; and conversely, an extensive inhibition zone can occur when the destruction of agglutinin has been nil, or when its power has actually been increased by the heating.

If the question were one of the formation of an agglutinoid at the expense of the agglutinin, then "zones of inhibited agglutination" of equal extent should appear whether bouillon culture or agar-culture suspensions are agglutinated; but this has been found not to be the case. And a final objection to this view of the origin of the "zones" lies in the fact that they may also appear when it is the bacterial culture that 
is exposed to heat, and not the agglutinin, and when the quantity of the substance formed by the heat is the same in every test tube of the series,-for each tube contains the same amount (1.5 c.c.) of the bacterial suspension or culture.

We are of the opinion that the phenomenon can be partly explained by the considerable retardation of the velocity of the reaction producing agglutination. In the process of heating the immune sera or the bacterial emulsion, compounds are formed which can impede agglutination of an agar-culture suspension when they are present in large amount, and accelerate it when present in small amount; in the latter case the action may perhaps be catalytic in nature.

The slowing of the velocity with which the agglutination proceeds is best seen when agar-culture suspensions are used. For example, in Series 61 a serum diluted with nine volumes of normal saline was warmed to $70^{\circ}$ for half an hour. Measurement of the agglutination it had produced in an agar-culture suspension after standing for one and a quarter hours at $37^{\circ}$ indicated that the serum's agglutinating power had fallen to $\frac{1}{T H}$ of its original value; after two and a half hours at $37^{\circ}$ it appeared to have fallen to one-seventh of its original value; about eighteen hours later its loss of agglutinating power was shown to have been quite small. In Series 62 the same heated serum was used to agglutinate a bouillon culture of $B$. coli; and the measurements, taken after the lapse of identical periods of time, indicated losses in agglutinating power represented by the figures $\frac{1}{2 \cdot 4}, \frac{1}{1 \cdot 4}, \frac{1}{1 \cdot 2}$ respectively.

So the conclusion may be drawn that the velocity of the process of agglutination is retarded far less with bouillon cultures than with agar-culture suspensions; and this fact corresponds with the observation so frequently made, that "zones of inhibited agglutination" are seen to occur far more frequently in the latter than in the former.

\section{The Action of Acids upon the Bacterial Suspensions.}

Malvoz was the first to draw attention to the fact that acids and certain other chemical substances are able to produce the agglutination of bacteria. This agglutination by acids cannot be distinguished from that produced by an immune serum, either macroscopically or by the use of the microscope. Hence there seems to be no just reason for believing that they are due to two different causes, as Nicolle and Defalle are inclined to do.

Neither Malvoz nor the investigators who have followed him, Lambotte and Bossaert, Sabrazès and Brengues, Defalle, Neisser and Friedemann, Craw, and others have given any exact description of the curious course taken by this acid agglutination. Our own experiments have been made for the most part with $B$. coli, which is referred to in all cases where no special notice to the contrary effect is given; a number of experiments were also made with cultures of $B$. typhosus. 
The results of the experiments once more illustrate the rule that the results obtained with agar-culture suspensions and bouillon cultures do not agree. The normal saline suspension of $B$. coli is very easily agglutinated by $\mathrm{HCl}$, while the bouillon culture is but difficultly so; but an emulsion in bouillon of the bacteria grown upon agar is, again, comparatively readily agglutinated by this acid.

The most striking characteristic of agglutination by an acid is the irregularity with which it proceeds, as is seen when the acid is added in steadily diminishing quantities to a long series of the test tubes.

Strong or complete agglutination is produced by both large and very small amounts of acid, while the intermediate quantities that lie between these two extremes produce little agglutination, or even none at all ; this is clearly illustrated by the figures given in Table XIX. This Table also exhibits the remarkable variability of the successive subcultures derived from a single stock of $B$. coli, and grown on a single cultivating medium; the variable agglutinability showing itself mainly in the agglutination produced by the very small amounts of acid.

Very important here is the degree of opacity of the bacterial emulsion employed, much more so than it is in the agglutination produced by an immune serum. This is shown by the fact that the "zone of inhibited agglutination" occupying the tubes intermediate between those contrining the large and the very small amounts of acid, when a normal emulsion is used, becomes smaller and smaller and finally disappears as stronger and stronger emulsions are employed, that is to say, emulsions containing more and more bacteria in a given volume; while at the same time the lower limit of agglutimation progressively rises, as is shown by the figures in Table XX. Series 75, where the experiments were made with orthophosphoric acid.

The agglutination of $B$. coli by acids, and the manner in which it occurs, resembles in many ways the "sedimentation" produced by the interaction of various substances and studied by Neisser and Friedemann. Thus, when a half-normal solution of ferric chloride is added to an aqueous suspension of gum mastic, the latter is precipitated ; using varying quantities of the ferric chloride solution, they found that intermediate zones might occur in which this sedimentation did not take place, and that these zones were progressively curtailed as stronger and stronger gum mastic suspensions were employed. This observation exactly agrees with what we have found to be the case in the agglutination of bacteria by acids, which shows that the phenomenon is not peculiar to the last-mentioned class of suspensions, and is of more general occurrence. The experiments of Neisser and Friedemann and of Beckold here referred to, contain many more points of interest that cannot be further discussed in this paper; it is to be hoped that further researches that are now under way will clear up a number of the questions that suggest themselves for solution. 
If an agar culture of $B$. coli be heated to from $50^{\circ}$ to $100^{\circ}$, it loses much of its capacity to be agglutinated by an acid; see Tables XXI. and XXII., in which the results of the same experiment are tabulated in two different ways for the sake of clearness. The figures given in Table XXII. record the fact that the agglutination of a suspension heated to $80^{\circ}$ may demand nineteen times as much orthophosphoric acid as is needed by the same emulaion when unheated, while that of a suspension kept at $100^{\circ}$ for an hour may require 1000 times as much acid as it does before the suspension has been heated at all. It is to be noticed that the first sudden diminution in agglutinability by an acid that is caused by heating occurs between the temperatures of $70^{\circ}$ and $80^{\circ}$, just as has been shown to be the case with the agglutination produced by an immune serum. This circumstance, too, speaks in just the same way against the view that the effect of heating the suspensions is to destroy certain specific substances in the bacteria, corresponding to the immune bodies in the agglutinating serum; but it affords support to the view held by us, namely, that a change takes place in the physical conditions under which the agglutination proceeds, and that the clumping of the bacteria is impeded.

Finding that different acids exhibited the power of agglutinating an emulsion of $B$. coli in very different degrees, we performed experiments with the object of ascertaining whether there was any connection between what is commonly known as the "strength" of an acid (as measured by its power of inverting cane sugar) and its power of agglutinating bacteria. The figures given in Series 77, Table XXIII., make it quite plain that it is impossible to find any connection between the sugar-inverting power of various acids and their power to agglutinate $B$. coli. It can here be seen, for example, that while hydrochloric acid has twenty-one times the sugar-inverting power of monochloracetic acid, it only possesses one-seventh of its power to agglutinate $B$. coli. There is one point serving to differentiate agglutination by an acid from that due to an immune serum that may be mentioned here, which is that bacterial suspensions that have been freed from excess of salts by dialysis can be agglutinated directly by an acid, while an immune serum can only produce agglutination when a salt has been added to the mixture. Thus agglutination by an acid does not demand that a salt should be present in quantities that can be readily detected by chemical means.

Before leaving the subject of agglutination by acids, it may be worth while to record briefly the action exerted upon its course by the addition of the normal serum of a horse; for this illustrates the conditions obtaining when an immune serum is used for agglutination after it has been treated with an acid, and may help in the elucidation of the phenomena there observed. In Table XXIV. are recorded the results of a single experiment. An emulsion of a twenty-four-hour agar culture of $B$. coli was divided into four parts, to three of which 
normal horse serum was added in the proportion of 10,1 , and $\overline{1}^{\frac{1}{0}}$ parts per mille; acting by itself, this horse serum was very feebly agglutinative, 0.2 c.c. being required to produce the minimum visible agglutination in 1.5 c.c. $B$. coli suspension, a quantity corresponding to 8.0 per cent. of the 2.5 c.c. present (as previously explained) in each test tube. This horse serum was not added to the emulsion used in column $A$, which therefore served as the control series. The experiment was then made of producing acid agglutination in the four sets of tubes, using $\mathrm{HCl}$ as agglutinant in the same amounts as in the experiments already described. It was found that quantities of $\mathrm{HCl}$ varying between 3.65 and 0.73 mgrms. per tube produced a feebler degree of agglutination in the control Series $A$ than was present in the tube selected as standard (denoted $S$ ), while in the columns $B$ and $C$ no agglutination at all was produced by from 3.65 to $0.4745 \mathrm{mgrm}$. $\mathrm{HCl}$. In column $\mathrm{D}$, on the other hand, a weak degree of agglutination was produced by from 3.65 to $2.19 \mathrm{mgrms}$. of $\mathrm{HCl}$, while no trace of agglutination at all was produced by from 1.825 to $0.4745 \mathrm{mgrms}$. of the acid. It is further seen that the smallest amounts of acid producing agglutination in the four sets of tubes were $0.04745 \mathrm{mgrm}$. in the two sets $A$ and $D$, and $0.06205 \mathrm{mgrm}$. in $C$, and 0.09125 mgrm, in B.

In other words, this experiment shows that when present in quantities of from 1.0 to 0.01 per cent., normal horse serum can lessen or prevent the agglutinating powers of both large and small quantities of acid, that are able to produce agglutination in the control series of test tubes, but that it may be without influence upon the intermediate amounts of the acid.

At the same time, the agglutination observed in set $D$ shows that the 0.01 per cent. of horse serum may have no recognisable influence upon the agglutinating action of the large or the small amounts of acid, but may yet impede the action of the intermediate quantities, thus increasing the extent of the already more or less well-marked " zone of inhibited agglutination" that so commonly occurs in the tubes that contain the intermediate amounts of acid.

The fact that the inhibiting influence of normal horse serum upon the agglutination caused by the acid does not follow the laws of simple proportion, is evident from the results given in columns $B, C$, and $D$; for while the addition of 0.1 per cent. of the serum diminishes the action of a given quantity of acid to about two-thirds of its usual value, the addition of 1.0 per cent. of the serum diminishes it to only one-half.

Proceeding now to give a short account of the agglutination by immune serum of $\mathrm{B}$. coli emulsion acidified by the addition of various quantities of acid, we have found, as experiments already detailed would lead one to expect, that the agglutinability exhibited by such acidified emulsions is extremely sensitive to minute variations in the amount of acid they contain. Thus it appeared that the addition of 
$\mathrm{HCl}$ in the proportion of $0.03 \mathrm{mgrms}$. to each test tube containing 1.5 c.c. $\frac{1}{\mathrm{~T}}$ normal emulsion-a quantity of acid that would produce a just visible agglutination if acting by itself alone-did not recognisably affect the agglutination caused by the immune serum; $0.06 \mathrm{mgrm}$. of the acid, which by itself would cause strong agglutination, may diminish the agglutinability of the suspension by serum to $\frac{1}{18}$ of the value it gives when not acidified; while both 0.24 and $0.48 \mathrm{mgrm}$. of acid, each of them quantities that would produce agglutination if acting alone, depressed the agglutinability to $\frac{1}{35}$. Hence acidification of the emulsion makes it much less easily agglutinated by the immune serum. At the same time, it makes the whole course of the agglutination liable to irregularities, and causes the occurrence of "zones of inhibition" and of paradoxical agglutination, in which a single tube at some point in a set may exhibit marked agglutination, while its immediate neighbours on either side show none. It is important to note that if the $B$. coli emulsion in which the acidification has prevented the occurrence of agglutination be suitably neutralised with $\mathrm{NaOH}$ solution, then agglutination ensues in a normal manner; this shows that there can be no question here of a destruction of the agglutinable group in the bacteria by the acid, similar to that which Eisenberg and Volk have assumed to take place in the case of B. typhosus.

So that the presence of these small quantities of $\mathrm{HCl}-$ quantities of 0.03 to $0.48 \mathrm{mgrm}$. of the acid in the 2.5 c.c. of immune serum, normal saline, and bacterial suspension made up as already describedthat would cause agglutination if acting alone, suffices to inhibit the agglutinating action of from 2 to 33 times the amount of immune serum that produces agglutination when acting by itself. And no agglutination at all may be produced in tubes that contain enough immune serum and enough acid to produce total agglutination by either of these substances if they were acting upon the emulsion separately instead of together.

Very similar conclusions were reached with our stock culture of B. typhosus.

The figures obtained in the researches detailed in the preceding paragraphs varied widely from one day to another, and were even contradictory. Hence it was not possible to arrive at definite numbers that would satisfactorily express the precise relations that exist here. For this reason we have contented ourselves with the qualitative statements given above.

\section{The Action of Acids upon the Agglutinating IMMUNE SERUM.}

The action of acid upon an agglutinating immune serum has been subjected to searching investigations at the hands of Pick, 
Eisenberg and Volk, and others. They have found that an acid can inhibit the specific action of the serum when it is present in sufficiently large quantities, but not if its quantity is small. These facts cannot be doubted, and the change produced in the immune serum by the acid is probably similar in nature to that produced by the action of heat upon it.

Eisenberg and Volk, who are followed by later experimenters, explain the phenomena by saying that a portion of the agglutinin is converted into agglutinoid. But they did not take the precaution in their experiments, so far as one is able to see, of measuring the quantity of free acid present in the various test tubes from which they drew their experimental results; nor do they state to what extent their bacterial stock could be agglutinated by hydrochloric acid acting alone. Hence it is possible that a portion of the agglutination they describe in the Tables of their results is due to a combination of acid and immune serum agglutination, or even to acid agglutination alone.

Our own researches were made in the following manner. Hydrochloric acid, in various quantities and in exactly measured degrees of dilution, was allowed to act upon the coli immune serum, either before or after its dilution, for about two hours at $37^{\circ}$. The acidified serum was then used for experiment, in some cases directly, in others after careful neutralisation with sodium hydrate solution. Its agglutinating power was measured on both agar-culture suspensions and bouillon cultures of the bacteria; as the results given later show, it is very important that cultures of both kinds should be employed. We examined the effects of both small and large quantities of the acid, allowing it to act upon the serum in strengths varying between $\frac{1}{7000}$ and about $\frac{3}{4}$ normal $\mathrm{HCl}$; some of the results obtained are set forth in Tables XXV. to XXXII., Series 79 to 90 . The figures in Series 81, Table XXVI., where the agglutinating power of the serum treated by acid was meusured upon an agar-culture suspension of $B$. coli, give evidence of the fact that extremely minute quantities of $\mathrm{HCl}$-from 0.0005 to 0.0007 per cent.-do not recognisably alter the agglutinating power of the immune serum; while amounts varying from 0.001 to 0.01 per cent. of acid usually make the serum more actively agglutinative than it was before the addition of the acid was made,- - but in these particular experiments it not infrequently happens that irregularities and "zones of inhibition" occur to interrupt the steady course of the agglutination. Yet such irregularities are not due directly to the amount of the acid which has been added, for they do not occur in the sets of tubes containing from 0.0005 to 0.0007 , or from 0.0025 to 0.015 per cent. of acid; but they are often seen in the sets of tubes containing intermediate amounts of acid, namely, from 0.001 to 0.002 per cent. To give a single instance of the intensifying influence of these small amounts of acid, the figures in 
Series 81 prove that the presence of $0.00013 \mathrm{mgrm}$. of $\mathrm{HCl}$ in the immune serum added to a tube can increase its agglutinating power fourfold.

The addition of somewhat larger amounts of $\mathrm{HCl}$ alters the agglutinating power of the serum in a different way. $A B$. coli agglutinating serum, diluted 1 to 100 , and acidified with $\mathrm{HCl}$ to $2 \cdot 439$ per mille (i.e. to about $\frac{1}{1} \frac{1}{3}$ normal $\mathrm{HCl}$.) as in Series 81, produces no agglutination in 1.5 c.c. agar suspension (diluted to 2.5 c.c.) when added in amounts of from 0.01 to 0.00085 c.c., although these quantities contain from 25 to $2 \cdot 13$ agglutinating units; but at the same time, from 0.00085 to 0.00012 c.c. of this acidified serum will produce nearly total agglutination, though 0.00012 c.c. represents only one-third of an agglutinating unit.

Thus it is clear that when the agglutinating power of the immune serum thus treated with acid is measured on an agar-culture suspension of $B$. coli, there are two limiting values to choose from-a higher one that proves the serum to be weaker than, and a lower one that proves it to be about three times as strong as, it was before it was treated with the acid. The question now arises, Which of these two values, if either, correctly represents the process that is being measured?

If the quantity of acid present in the different test tubes that are agglutinated to the same degree as the tube chosen as standard be calculated, it is found that they all contain more or less the same amount of acid, whether the agglutinating power appear to be diminished or increased, and although the various sera used have been treated with widely differing quantities of acid and are present in widely varying amounts. The numbers given in Series 81 , for example, show that in the several sets of test tubes in which the differently acidified sera-which contain from 0.408 to 2.493 parts per mille of $\mathrm{HCl}$ - have been added, the lower limit of agglutination to the standard degree always occurs in the tubes containing from 0.029 to $0.026 \mathrm{mgrm}$. $\mathrm{HCl}$, while the amount of the agglutinating serum in these tubes varies between 0.00012 and 0.0007 c.c.

These facts cannot be properly appreciated until the ability of the $\mathrm{HCl}$ to produce agglutination when it is acting alone has been measured.

Series 81 shows that in this particular agar suspension, agglutination as strong as or even stronger than that in the standard tube was produced by quantities of from 0.146 to $0.026 \mathrm{mgrm}$. of $\mathrm{HCl}$.

Hence the apparent increase in the agglutinating power of the serum depends upon the presence of these small amounts of acid (from 0.029 to $0.026 \mathrm{mgrm}$.) which are capable of producing the agglutination by themselves alone; and the experiments just recorded prove that the agglutinating action of these small quantities of acid is not prevented by the particular amounts of immune serum that are being considered here. So much then for the lower limit of the "zone." 
For the position of its upper limit, at which it comes to an end, very similar considerations hold good. The tubes that are agglutinated to the same extent in the different series are found to contain nearly the same (or the calculated) amount of acid, quite independently of the amount of acid with which the sera were treated, or of the quantity of serum present in these tubes. The experiments in Series 81,84 , and 88 bring this out clearly. One cannot help a feeling of surprise that the quantities observed should tally so closely with those calculated, for the upper limit of the zone as well as for the lower.

It will also be noticed that when the measurements are made in an agar-culture suspension, the extent of the inhibition zone produced by the acidified serum does not, within wide limits, vary with the amount of acid with which the serum was treated, but depends solely upon the amount of acid present in the quantity of acidified serum placed in the given tubes; this can be seen by reference to Series 82 .

The figures given in Table XXXII., Series 90, illustrate the fact that a precisely similar explanation may be given of the "zone of inhibition" observed when an emulsion of B. typhosus, derived from our stock culture, is exposed to the action of acidified $B$. typhosus immune serum.

Thus we are unable to accept the explanation of the phenomena here described that has been given by other experimenters.

Our own view of the diminished agglutinating power and of the "zones of inhibited agglutination" met with in the acidified sera is that both are mainly if not entirely due to diminution in the velocity of the reaction, this diminution being caused by the presence, in certain proportions, of the acid. The apparent increase in the agglutinating power of the serum is due solely to the power possessed by the acid of agglutinating per se when it is present in sufficient quantity.

Inspection of the figures set down in Tables XXX. and XXXI., Series 88 and 89 , brings out the fact that there are striking differences between the two readings obtained, the one immediately after the tubes have been in the water bath at $37^{\circ}$ for one and a half hours, the other after they have stood for a further eighteen hours at the temperature of the room. The extent of the "inhibition zone" is much diminished in the latter case, and the apparent loss in agglutinating power experienced by the serum is much less. It is evident, too, that the important factor here is not the strength of the acid to which the immune serum was exposed, but that it is the amount of acid added (in the form of acidified serum) to the tubes at the "zone's" upper and lower limits.

The experimental results detailed in Series 88 and 89 show that although the agglutinating serum employed in one set of tubes may be treated with ten or fifteen times as much acid as in the serum used in another set, yet the "zone of inhibited agglutination" will 
come to an end, in either case, at that tube in which the amount of acid added in the form of acidified serum is less than about $0.2 \mathrm{mgrm}$; jet in the one case the amount of agglutinating serum present in this tube is some twenty-two times as great as it is in the other.

Hence there can be no question here of the conversion of agglutinin into agglutinoid, as Eisenberg and Volk and others have supposed to be the case. The experiments just detailed prove this, and further proof is given by the fact that by suitable neutralisation of the acidified serum both the zone of inhibited agglutination and the apparent increase or reduction in the agglutinative power of the serum disappear, completely or nearly so, this depending upon the amount of acid with which the immune serum was originally treated.

Since our results stand in absolute contradiction to those found by Eisenberg and Volk, it is necessary to look more closely into the significance of this neutralisation of the acidified serum and certain other points.

The method of experiment was as follows:- The immune serum was exposed to the action of the acid for two hours at $37^{\circ}$ in a water bath. The subsequent neutralisation of a portion of it is, however, a matter of no little difficulty; for some compound is formed between the acid and the serum that is but slowly decomposed by the alkali ( $\mathrm{NaOH}$ solution) towards the end of the neutralisation, or even when the alkali is present in slight excess. The effect of this is that when almost the whole of the calculated quantity of $\mathrm{NaOH}$ solution has been added to the acidified serum that is to be neutralised, the mixture shows a markedly alkaline reaction with phenol-phthalein; but less than half an hour later it will be acid again, and this alternation can be repeated several times in succession by the slow addition of the alkaline solution. Hence it is impossible to neutralise an acidified serum with any great degree of chemical precision. A further difficulty arises from the fact that a serum unites equally readily with either an acid or an alkali ( $\mathrm{HCl}$ or $\mathrm{NaOH}$ ). As the destructive effect of an alkali upon the agglutinin is much stronger than that of an acid, a new factor appears which must not be overlooked when an estimate of the destructive effect of an acid upon an agglutinating immune serum is being estimated by the results of neutralisation experiments such as those described above; and it must be mentioned finally that when even very small amounts of acid are present, fluctuations in their value exert a very powerful influence upon the agglutination produced by an immune serum.

Tables XXVII. to XXXI. record the results obtained when the serum is first treated with an acid and then neutralised. They show that, speaking generally, the "zones of inhibition" and the increased agglutinating power both disappear on neutralisation. With reference to the diminution that sometimes occurs in the agglutinating power, it is to be observed that when comparatively small amounts of the 
acid have been employed the return of agglutinating power to the serum on neutralisation is almost complete; but that if larger and larger quantities of the acid are allowed to act upon the serum and the mixture is then neutralised, the reduction of the agglutinating power does grow progressively greater and greater. Still, a part at least of the agglutinating power always returns (within wide limits, that is to say) where neutralisation is performed.

In the same way the velocity with which the agglutination takes place is very considerably diminished when the immune serum has been treated, before neutralisation, with tolerably large quantities of $\mathrm{HCl}$-with three-fourths normal $\mathrm{HCl}$, for example. The figures set down in Series 88 and 89 , where the serum was treated with 2.283 per cent. $\mathrm{HCl}$, show that after the neutralised serum had acted for one and a half hour at $37^{\circ}$ upon the bacterial emulsion, its agglutinating power appeared to be only one-seventeenth and oneseventh, in the two cases respectively, of that of the untreated serum. The same test tubes, examined eighteen hours later, showed that their powers were by that time only reduced to one-fifth and one-balf of what they had been before they were acidified.

All of the observations quoted above were made upon agarculture suspensions of $B$. coli.

The results obtained from bouillon cultures are both qualitatively and quantitatively different. This is shown to be the case by the results of experiments made simultaneously upon the same day and with identical dilutions of the immune serum, so that they are as strictly comparable one with another as is possible.

It is made evident in Tables XXV., XXVIII., and XXIX., Series 79,80 , and 84 to 87 , that with bouillon cultures the "zones of inhibited agglutination" are a less prominent feature. They do not occur unless the serum has been treated with very considerable quantities of acid,-_quantities that are perhaps twenty or thirty times as great as those required to produce "zones" when the agar-culture suspension is employed. None the less, however, the agglutinating power of the immune serum may be reduced to one-nineteenth of its original value under such conditions as these - see Table XXV., Series 80 .

But if the acidified serum is neutralised before use with the bouillon cultures, it becomes apparent that in this case also the loss of its agglutinating power is to some extent apparent rather than real; for with neutralisation the serum recovers its agglutinating power to a large extent, or even entirely.

Still, Tables XXVIII, and XXIX. show that the actual destruction of the rcidified immune serum's agglutinating power is greater if bouillon culture is employed for the measurements than when an agar-culture suspension is used.

If a bouillon culture is made use of, one does not observe an 
increase in the serum's agglutinating power, as may be the case when a suspension is made the subject of the experiment. As has already been pointed out, this is because a bouillon culture is not readily agglutinated by an acid, so that the minute quantities of acid that have come into play are unable to produce an apparent increase in the serum's capacity for producing agglutination.

The experiments suffice to show also that in the case of bouillon cultures the extent of the "zones of inhibition" observed does not depend upon the actual destruction of the agglutinin that has taken place,-the limits of the "zone" are determined by the presence of just such an amount of acid in the tubes where it occurs as will prevent the bacteria from coming together, and bear no relation to the strength of the acid to which the serum was exposed.

In conclusion, we shall give a brief account of the experiments wo have made that illustrate-

\section{The Action of Alkalugs upon the Procesg of Agglutination.}

We have never been able to find that solutions of caustic soda (NaOH) have any agglutinating influence upon our stocks of $B$. coli or $B$. typhosus, whether added in large quantities or in small. Like other experimenters, however, we have observed that even when added to the bacterial emulsion in relatively small quantities, the alkali renders it more translucent. It appears that $B$. coli suspensions to which regularly increasing amounts of caustic soda have been added, just as acid was added in the experiments already described, lose much of their power of being agglutinated by immune serum. The agglutinability grows progressively less as increasing quantities of the alkali are added. But such experiments as we have made in this direction have failed to bring to our observation any such irregularities in the agglutination, or any of the "zones of inhibited agglutination" that are of such frequent occurrence when acid is made use of. With the alkali, diminishing amounts of the immune serum always produce diminishing degrees of agglutination.

Acting upon the agglutinin of $B$. coli immune serum, caustic soda is far more destructive than is an equimolecular solution of hydrochloric acid. For example, $\mathrm{HCl}$ of $\frac{1}{120}$ normal strength destroys practically none of the agglutinin; while the equimolecular $\mathrm{NaOH}$ solution, acting under identical circumstances, may reduce the agglutinating power of the immune serum to one-thirtieth of its original value.

Still, in the case of the alkali, as with the acid, the apparent destruction of the agglutinating power is greater than the actual destruction, as is shown when the alkalised serum is neutralised with the calculated quantity of $\mathrm{HCl}$, and two series of tubes are set up, 
one for the alkalised serum and the other for the same serum after it has been thus neutralised by the addition of $\mathrm{HCl}$.

But although the actual destruction of agglutinin is greater in the case of the alkali than it is with the acid, there is much less tendency to the appearance of "zones of inhibited agglutination" and the other irregularities already detailed, in the former case than there is in the latter.

And here again we would advance the view that the phenomena are largely due to a diminution of the velocity with which the reactions proceed in the presence of certain quantities of $\mathrm{NaOH}$, in opposition to the theory, given by Eisenberg and Volk and others, that it is due to the conversion of agglutinin into agglutinoid. For it was invariably the case that, if the observations of the agglutination were made after the tubes had stood for one and a half to two hours at $37^{\circ}$, the loss in agglutinating power exhibited by the serum was much greater than it proved to be if the measurements were deferred until the tubes had stood for a further eighteen hours at the temperature of the room. 


\section{APPENDIX.}

\section{TABLES I.-XXXII.}

THr meanings of the abbreviations and of the figures given in the Tables are as follows:-

A.A.-The absolute amount of the immune serum, measured in c.c., needed to produce a degree of agglutination equal to that present in the test tube selected as standard.

R.A.-The relative amount of the immune serum necessary to produce the given degree of agglutination. The actual amount of the serum which is taken as equal to unity here is given, in c.c., beneath the letters themselves.

The sign > placed in front of a set of figures in the Tables indicates that this amount of agglutinating immune serum produces either no agglutination or an agglutination less than that present in the test tubé selected as standard.

The sign < placed in front of a set of figures in the Tables indicates that this amount of agglutinating immune serum produces a stronger agglutination than that present in the test tube selected as standard.

When two sets of figures are put together in a column in place of the usual single figure, as occurs for the first time in Table II., Series 8 , in the case of the emulsion heated up to $90^{\circ}$, this implies that such a set of tubes began at some point in a "zone of inhibited agglutination." The effect of this is, that there are two tubes lower down in the set showing a degree of agglutination equal to that seen in the tube selected as standard, Madsen's method of measurement being employed.

When three sets of figures are given together in a column, the sign $>$ or $<$ will always be found in front of, at least, one set.

The three sets of figures similarly imply that a "zone of inhibited agglutination" occurred; but in these cases it was preceded by tubes either showing or not showing agglutination, and followed by tubes showing agglutination.

In such cases, therefore, a standard degree of agglutination occurs twice (or sometimes three times) on passing down the set of tubes. 
TABLE I.

\begin{tabular}{|c|c|c|c|c|c|c|c|c|c|c|c|}
\hline & & \multicolumn{2}{|c|}{$\begin{array}{l}\text { Series } 1 . \\
\text { B. coli Agar } \\
\text { Suspension. }\end{array}$} & \multicolumn{2}{|c|}{$\begin{array}{l}\text { Series 2. } \\
\text { B. typhosus Agar } \\
\text { Suspension. }\end{array}$} & \multicolumn{2}{|c|}{$\begin{array}{l}\text { Series 3. } \\
\text { B. coli Bouillon } \\
\text { Culture. }\end{array}$} & \multicolumn{2}{|c|}{$\begin{array}{l}\text { Serios 4. } \\
\text { B. coli Bouillon } \\
\text { Culture. }\end{array}$} & \multicolumn{2}{|c|}{$\begin{array}{l}\text { Series 5. } \\
\text { B. coli Boullilon } \\
\text { Culture. }\end{array}$} \\
\hline & & $\begin{array}{l}\text { A.A. } \\
\text { C.C. }\end{array}$ & 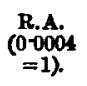 & $\begin{array}{l}\text { A.A. } \\
\text { c.c. }\end{array}$ & $\begin{array}{l}\text { R.A } \\
\left(\begin{array}{c}\text { (0.A } \\
=1) .018\end{array}\right.\end{array}$ & $\begin{array}{l}\text { A.A. } \\
\text { c.c. }\end{array}$ & $\begin{array}{l}\text { R.A. } \\
\text { (0.0003 } \\
=1) .\end{array}$ & $\begin{array}{l}\text { A.A. } \\
\text { c.c. }\end{array}$ & $\begin{array}{l}\text { R.A. } \\
\left(\begin{array}{l}(0.0017 \\
=1)\end{array}\right.\end{array}$ & $\begin{array}{l}\text { A.A. } \\
\text { C.c. }\end{array}$ & $\begin{array}{l}\text { R.A. } \\
\left(\begin{array}{l}0.0013 \\
=1)\end{array}\right.\end{array}$ \\
\hline $\begin{array}{l}\text { Culture- } \\
24 \text { hours }\end{array}$ & - & 0.0004 & 1.0 & 0.0018 & $1 \cdot 0$ & 0.0003 & 1.0 & 0.0017 & 1.0 & 0.0013 & 10 \\
\hline 3 days & - & 0.0004 & $1 \cdot 0$ & 0.002 & $1 \cdot 1$ & 0.00087 & $2 \cdot 9$ & 0.0078 & $4: 59$ & $\ldots$ & $\ldots$ \\
\hline 5, & . & 0.00045 & $1 \cdot 13$ & 0.0022 & 1.22 & 0.0012 & $4 \cdot 0$ & 0.0098 & $5 \cdot 76$ & $\ldots$ & $\ldots$ \\
\hline $12 "$ & . & 0.00038 & 0.95 & $0-0018$ & $1 \cdot 0$ & 0.0048 & $16 \cdot 0$ & 0.03 & $17 \cdot 6$ & 0.038 & $29 \cdot 2$ \\
\hline 19, & & 0.00046 & $1 \cdot 15$ & 0.0018 & 1.0 & 0.0048 & 16.0 & 0.036 & $21 \cdot 2$ & $\ldots$ & $\ldots$ \\
\hline 52, & - & 0.00045 & $1 \cdot 13$ & 0.002 & $1 \cdot 1$ & $\ldots$ & $\ldots$ & $\ldots$ & $\ldots$ & $\ldots$ & $\ldots$ \\
\hline 62 ". & . & 0.00048 & 1.2 & 0.0025 & 1.39 & $\ldots$ & $\ldots$ & $\ldots$ & $\ldots$ & $\ldots$ & $\ldots$ \\
\hline
\end{tabular}

TABLE II.

\begin{tabular}{|c|c|c|c|c|c|c|c|c|c|c|}
\hline & \multicolumn{2}{|c|}{$\begin{array}{c}\text { Series 6. } \\
\text { 24-Hours B. coli } \\
\text { Agar Bugpension. }\end{array}$} & \multicolumn{2}{|c|}{$\begin{array}{l}\text { Beries 7. } \\
\text { 24-Hours B. coli } \\
\text { Agar Buspension. }\end{array}$} & \multicolumn{2}{|c|}{$\begin{array}{c}\text { Beries 8. } \\
\text { 24-Hours B. coli } \\
\text { Agar Suspension. }\end{array}$} & \multicolumn{2}{|c|}{$\begin{array}{c}\text { Series 9. } \\
\text { 24-Hours B. coli } \\
\text { Agar Buspension. }\end{array}$} & \multicolumn{2}{|c|}{$\begin{array}{l}\text { Series } 10 . \\
\text { 24-Hours B. coli } \\
\text { Agar Bugpension. }\end{array}$} \\
\hline & $\begin{array}{l}\text { A.A. } \\
\text { c.c. }\end{array}$ & $\begin{array}{l}\text { R.A. } \\
(1 \cdot 0004 \\
=1) .\end{array}$ & $\begin{array}{l}\text { A.A. } \\
\text { c.c. }\end{array}$ & $\begin{array}{l}\text { R.A. } \\
(0.00025 \\
=1)\end{array}$ & $\begin{array}{l}\text { A.A. } \\
\text { c.c. }\end{array}$ & $\begin{array}{c}\text { R.A. } \\
(0.0004 \\
=1) .\end{array}$ & $\begin{array}{l}\text { A.A. } \\
\text { c.c. }\end{array}$ & 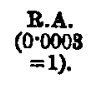 & $\begin{array}{l}\text { A.A. } \\
\text { c.c. }\end{array}$ & $\begin{array}{l}\text { R.A. } \\
\left(\begin{array}{c}0.0004 \\
=1) .\end{array}\right.\end{array}$ \\
\hline $\begin{array}{c}\text { Culture-- } \\
\text { Unheated }\end{array}$ & 0.0004 & $1 \cdot 0$ & 0.00025 & $1 \cdot 0$ & 0.0004 & 1.0 & 0.0003 & $1 \cdot 0$ & 0.0004 & 1.0 \\
\hline Heated to $40^{\circ}$ & 0.0005 & 1.25 & 0.00028 & $1 \cdot 12$ & 0.00052 & 1.3 & 0.00028 & 0.93 & 0.0004 & $1 \cdot 0$ \\
\hline$\Rightarrow \quad 50^{\circ}$ & 0.0005 & $1 \cdot 25$ & 0.00038 & 1.52 & 0.00048 & 1.2 & 0.0004 & 1.33 & 0.0004 & 1.0 \\
\hline$" \quad 60^{\circ}$ & 0.0007 & $1 \cdot 75$ & 0.0005 & $2 \cdot 0$ & 0.00058 & 1.45 & 0.00048 & $1 \cdot 6$ & 0.00055 & 1.38 \\
\hline $70^{\circ}$ & 0.0009 & $2 \cdot 25$ & 0.0007 & $2 \cdot 8$ & 0.00065 & 1.63 & 0.00055 & 1.83 & 0.00065 & $1 \cdot 63$ \\
\hline $75^{\circ}$ & $\cdots$ & $\cdots$ & $\cdots$ & $\cdots$ & $\cdots$ & $\cdots$ & $\ldots$ & $\cdots$ & 0.0025 & $6 \cdot 25$ \\
\hline $80^{\circ}$ & 0.018 & $45 \cdot 0$ & 0.0025 & 10.0 & 0.0058 & 14.5 & 0.0048 & 16.0 & 0.005 & $12 \cdot 5$ \\
\hline$\Rightarrow \quad 90^{\circ}$ & $>0.02$ & $>50.0$ & 0.008 & 12.0 & $\begin{aligned}>0.011 \\
0.0075\end{aligned}$ & $\begin{aligned}> & 25 \cdot 0 \\
& 18.75\end{aligned}$ & $>0.01$ & $>33.3$ & $\begin{array}{l}0.05 \\
0.0115\end{array}$ & $\begin{array}{c}125 \cdot 0 \\
28 \cdot 75\end{array}$ \\
\hline$\Rightarrow \quad 100^{\circ}$ & $>0.02$ & $>50.0$ & 0.0035 & $14 \cdot 0$ & 0.007 & $17 \cdot 5$ & $>0.01$ & $>33.3$ & $\begin{array}{l}0.007 \\
0.0115\end{array}$ & $\begin{array}{l}17 \cdot 5 \\
28 \cdot 75\end{array}$ \\
\hline
\end{tabular}

1 See the explanation preceding Table I. 
TABLE III.

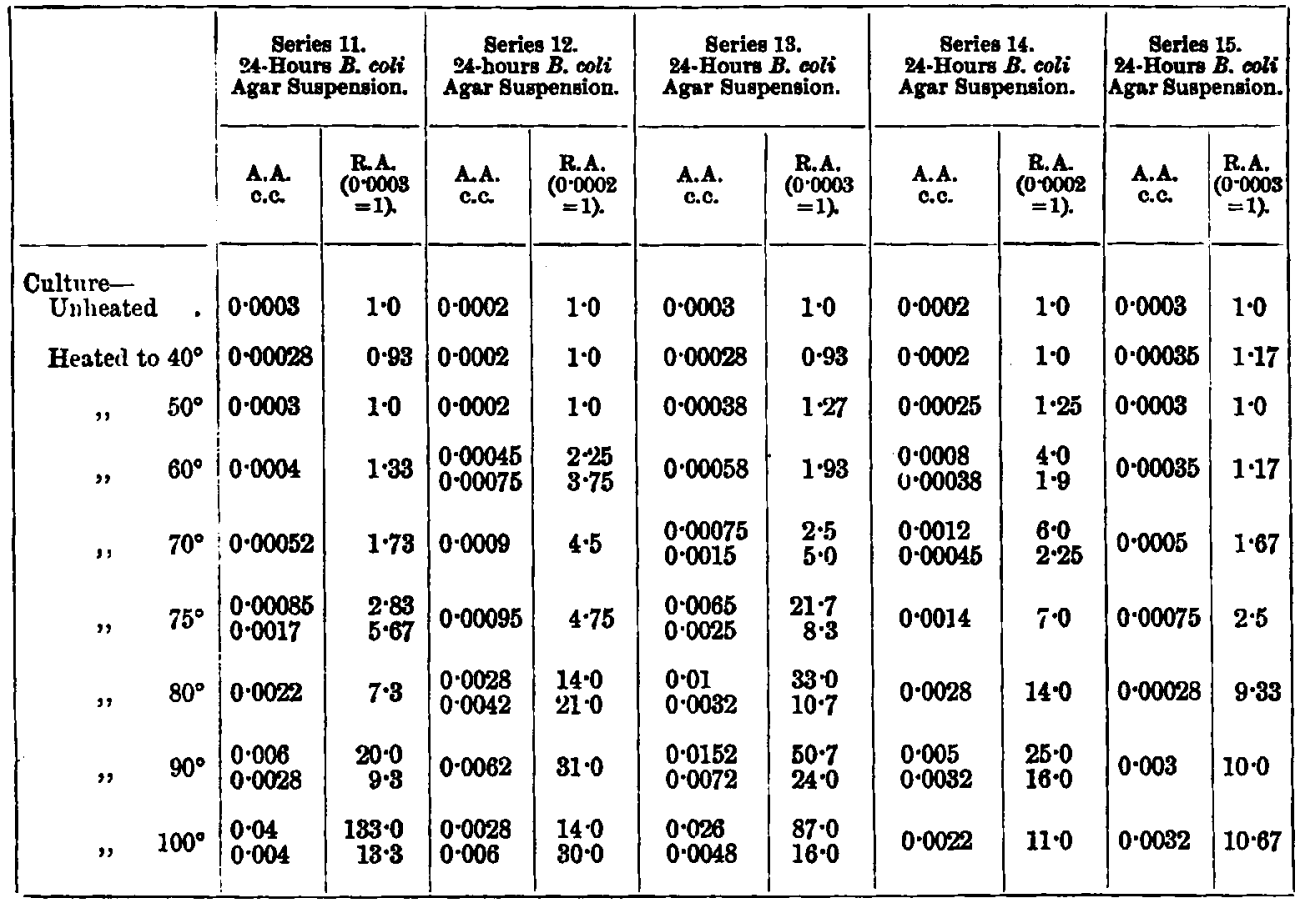

TABLE IV.

\begin{tabular}{|c|c|c|c|c|c|c|c|c|c|c|}
\hline & \multicolumn{2}{|c|}{$\begin{array}{c}\text { Series 16. } \\
\text { 24-Hours B. coli } \\
\text { Agar Suspension. }\end{array}$} & \multicolumn{2}{|c|}{$\begin{array}{l}\text { Series 17. } \\
\text { 24-Hours B. coli } \\
\text { Agar Bugpension. }\end{array}$} & \multicolumn{2}{|c|}{$\begin{array}{c}\text { Series } 18 . \\
\text { o4-Hours B. coli } \\
\text { Agar Suspension. }\end{array}$} & \multicolumn{2}{|c|}{$\begin{array}{c}\text { Series 19. } \\
\text { 24-Hours B. coli } \\
\text { Agar Suspension. }\end{array}$} & \multicolumn{2}{|c|}{$\begin{array}{c}\text { Beries 20. } \\
\text { 24-Hours B. coli } \\
\text { Agar Suspension. }\end{array}$} \\
\hline & $\begin{array}{l}\text { A.A. } \\
\text { c.c. }\end{array}$ & $\begin{array}{l}\text { R.A. } \\
\substack{\text { (0.0004 } \\
=11 .}\end{array}$ & A.A. & $\begin{array}{l}\text { R.A. } \\
\left(0^{0.0004}\right. \\
=1) .\end{array}$ & $\begin{array}{l}\text { A.A. } \\
\text { c.c. }\end{array}$ & $\begin{array}{l}\text { R.A. } \\
\left(0^{0} 00017\right. \\
=1) .\end{array}$ & $\begin{array}{l}\text { A.A. } \\
\text { c.c. }\end{array}$ & $\begin{array}{l}\text { R.A. } \\
\left(\begin{array}{l}\text { (0.0003 } \\
=1) .\end{array}\right.\end{array}$ & $\begin{array}{l}\text { A.A. } \\
\text { c.c. }\end{array}$ & $\begin{array}{l}\text { R.A. } \\
\text { (0000011 } \\
=1) .\end{array}$ \\
\hline $\begin{array}{l}\text { Culture-- } \\
\text { Unheated }\end{array}$ & 0.0004 & $1 \cdot 0$ & 0.0004 & 1.0 & 0.00017 & $1 \cdot 0$ & 0.0003 & 1.0 & 0.00011 & $1 \cdot 0$ \\
\hline Heated to $40^{\circ}$ & 0.00035 & 0.86 & 0.00038 & 0.95 & 0.0002 & $1 \cdot 18$ & 0.00028 & 0.98 & 0.00012 & 1.09 \\
\hline $50^{\circ}$ & 0.00035 & 0.86 & 0.0004 & $1 \cdot 0$ & 0.0003 & $1 \cdot 76$ & 0.00025 & 0.83 & 0.00012 & 1.09 \\
\hline$\Rightarrow \quad 60^{\circ}$ & 0.0005 & $1 \cdot 25$ & 0.00055 & $1 \cdot 38$ & 0.00055 & $3 \cdot 24$ & 0.0003 & $1 \cdot 0$ & 0.00015 & $1 \cdot 27$ \\
\hline $70^{\circ}$ & 0.00058 & 1.45 & 0.00065 & $1 \cdot 68$ & 0.00065 & $3 \cdot 82$ & 0.00038 & $1 \cdot 27$ & 0.0002 & 1.82 \\
\hline $75^{\circ}$ & $\begin{array}{l}0.0009 \\
0.00185\end{array}$ & $\begin{array}{l}2-25 \\
4.63\end{array}$ & $\begin{array}{l}0.0095 \\
0.0025\end{array}$ & $\begin{array}{r}23 \cdot 75 \\
6 \cdot 25\end{array}$ & $\cdots$ & $\cdots$ & $\cdots$ & $\cdots$ & 0.00065 & 5.9 \\
\hline $80^{\circ}$ & 0.003 & $7 \cdot 5$ & 0.003 & $7 \cdot 5$ & 0.0045 & $26 \cdot 5$ & 0.002 & 6.67 & 0.001 & $9 \cdot 09$ \\
\hline$\Rightarrow \quad 90^{\circ}$ & 0.0038 & $9 \cdot 5$ & $>0.01$ & $\begin{array}{r}>25.0 \\
11.25\end{array}$ & 0.006 & $35 \cdot 3$ & 0.0025 & 8.33 & 0.0009 & $8 \cdot 2$ \\
\hline$\Rightarrow \quad 100^{\circ}$ & 0.0025 & $6 \cdot 25$ & $\begin{array}{l}0.01 \\
0.0045\end{array}$ & $\begin{array}{l}25 \cdot 0 \\
11 \cdot 25\end{array}$ & 0.006 & $35 \cdot 3$ & 0.0025 & 8.33 & 0.0012 & $10 \cdot 9$ \\
\hline
\end{tabular}


TABLE V.

\begin{tabular}{|c|c|c|c|c|c|c|c|c|c|c|c|}
\hline & \multicolumn{2}{|c|}{$\begin{array}{l}\text { Series 21. } \\
\text { 36-Hours B. coli } \\
\text { Agar Suspension. }\end{array}$} & \multicolumn{2}{|c|}{$\begin{array}{l}\text { Series } 92 . \\
\text { 48-Hours B. coli } \\
\text { Agar Suspension. }\end{array}$} & \multicolumn{2}{|c|}{$\begin{array}{c}\text { Series } 23 . \\
\text { 4-Days } B . \text { coli } \\
\text { Agar Buspension. }\end{array}$} & \multicolumn{2}{|c|}{$\begin{array}{c}\text { Series 24. } \\
\text { 50-Days B. coli } \\
\text { Agar Suspension. }\end{array}$} & \multicolumn{2}{|c|}{$\begin{array}{c}\text { Series } 25 . \\
\text { 50-Days B. coli } \\
\text { Agar Suspension. }\end{array}$} \\
\hline & & $\begin{array}{l}\text { A.A. } \\
\text { c.c. }\end{array}$ & $\begin{array}{l}\text { R.A. } \\
(0 \cdot 0002 \\
=1) .\end{array}$ & $\begin{array}{l}\text { A.A. } \\
\text { c.c. }\end{array}$ & $\begin{array}{l}\text { R.A. } \\
\left(0^{\circ} 0008\right. \\
=1) .\end{array}$ & $\begin{array}{l}\text { A.A. } \\
\text { c.c. }\end{array}$ & $\begin{array}{l}\text { R.A. } \\
(0.00028) \\
=1)\end{array}$ & $\begin{array}{l}\text { A.A. } \\
\text { c.c. }\end{array}$ & $\begin{array}{l}\text { R.A. } \\
\left(0^{\circ} 0007\right. \\
=1)\end{array}$ & $\begin{array}{l}\text { A.A. } \\
\text { c.c. }\end{array}$ & $\begin{array}{l}\text { R.A. } \\
\left(0^{\circ} \cdot 00045\right. \\
=1)\end{array}$ \\
\hline \multicolumn{2}{|c|}{$\begin{array}{l}\text { Culture- } \\
\text { Unheated }\end{array}$} & 0.0002 & $1 \cdot 0$ & 0.0008 & $1 \cdot 0$ & 0.00028 & $1 \cdot 0$ & 0.0007 & $1 \cdot 0$ & 0.00045 & $1 \cdot 0$ \\
\hline \multicolumn{2}{|c|}{ Heated to $40^{\circ}$} & 0.00022 & $1 \cdot 1$ & 0.00085 & 1.06 & 0.00028 & $1 \cdot 0$ & 0.00072 & 1.03 & 0.0005 & $1 \cdot 11$ \\
\hline & $50^{\circ}$ & 0.00035 & $1 \cdot 75$ & 0.0008 & $1 \cdot 0$ & 0.00028 & $1 \cdot 0$ & 0.0007 & $1 \cdot 0$ & 0.0005 & $1 \cdot 11$ \\
\hline & $60^{\circ}$ & 0.0005 & $2 \cdot 5$ & 0.00078 & 0.98 & 0.0004 & $1 \cdot 43$ & 0.00075 & $1 \cdot 07$ & 0.00055 & $1 \cdot 22$ \\
\hline$"$ & $70^{\circ}$ & 0.0008 & $4 \cdot 0$ & 0.0008 & $1 \cdot 0$ & 0.0005 & $1 \cdot 79$ & 0.0009 & $1 \cdot 29$ & 0.0006 & 1.33 \\
\hline$"$ & $75^{\circ}$ & $\cdots$ & $\ldots$ & $\cdots$ & $\ldots$ & 0.0006 & $2 \cdot 14$ & $\cdots$ & $\cdots$ & $\cdots$ & $\cdots$ \\
\hline$"$ & $80^{\circ}$ & 0.002 & 10.0 & 0.003 & $3 \cdot 75$ & 0.0025 & $8 \cdot 93$ & 0.0022 & $3 \cdot 14$ & 0.001 & $2 \cdot 22$ \\
\hline$"$ & $90^{\circ}$ & 0.0038 & $19 \cdot 0$ & 0.003 & $3 \cdot 75$ & 0.0025 & $8 \cdot 93$ & 0.0025 & $3 \cdot 57$ & 0.0012 & $2 \cdot 67$ \\
\hline$"$ & $100^{\circ}$ & 0.004 & $20 \cdot 0$ & $\begin{array}{l}0.032 \\
0.0072\end{array}$ & $\begin{array}{r}40.0 \\
9.0\end{array}$ & 0.0026 & $9 \cdot 29$ & 0.0025 & $3 \cdot 57$ & 0.0012 & $2 \cdot 67$ \\
\hline
\end{tabular}

TABLE VI.

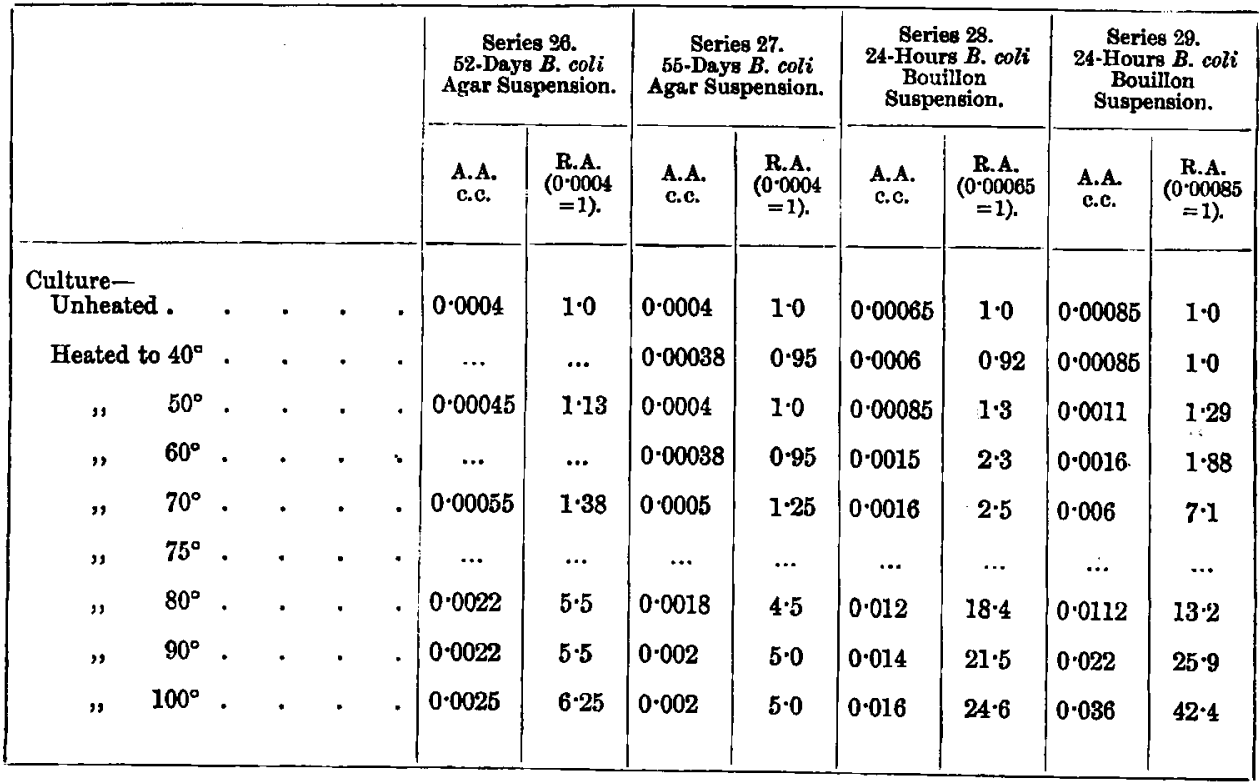


TABLE VII.

\begin{tabular}{|c|c|c|c|c|c|c|c|}
\hline & & \multicolumn{2}{|c|}{$\begin{array}{l}\text { Series } 30 . \\
\text { 24.Hours B. typhoous } \\
\text { Agar Buspension. }\end{array}$} & \multicolumn{2}{|c|}{$\begin{array}{l}\text { Series 31. } \\
\text { 24-Hours B. typhosus } \\
\text { Agar Suspension. }\end{array}$} & \multicolumn{2}{|c|}{$\begin{array}{l}\text { Series 32. } \\
\text { 62-Days B. typhogus } \\
\text { Agar Sugpension. }\end{array}$} \\
\hline & & A.A. & $\underset{(0.00035=1)}{\mathbf{R . A} .}$ & $\begin{array}{l}\text { A.A. } \\
\text { c.c. }\end{array}$ & $\begin{array}{c}\text { R.A. } \\
0.0008=1) .\end{array}$ & A.A. & $\begin{array}{l}\text { R.A. } \\
0.0018=1) .\end{array}$ \\
\hline $\begin{array}{c}\text { Culture-- } \\
\text { Unheated }\end{array}$ & . & 0.00035 & $1 \cdot 0$ & 0.0008 & 1.0 & 0.0018 & $1 \cdot 0$ \\
\hline Heated to $40^{\circ}$. & . & 0.00035 & 1.0 & 0.0009 & $1 \cdot 13$ & 0.0019 & 1.06 \\
\hline$" \quad 50^{\circ}$. & . & 0.0004 & $1 \cdot 14$ & 0.001 & $1 \cdot 25$ & 0.0018 & 1.0 \\
\hline$" \quad 60^{\circ}$. & .. & 0.0008 & $2 \cdot 3$ & 0.0022 & $2 \cdot 75$ & 0.002 & $1 \cdot 11$ \\
\hline $70^{\circ}$. & . & 0.002 & $5 \cdot 7$ & 0.005 & 6.25 & 0.003 & 1.67 \\
\hline $75^{\circ}$. & - & $\ldots$ & $\ldots$ & $\ldots$ & $\ldots$ & $\ldots$ & $\ldots$ \\
\hline $80^{\circ}$. & . & 0.006 & $17 \cdot 1$ & 0.005 & 6.25 & 0.005 & $2 \cdot 78$ \\
\hline $90^{\circ}$. & . & 0.016 & $45 \cdot 7$ & 0.015 & 18.75 & 0.005 & $2 \cdot 78$ \\
\hline$" \quad 100^{\circ}$. & . & 0.016 & $45 \cdot 7$ & 0.018 & 22.5 & 0.0055 & 3.06 \\
\hline
\end{tabular}

TABLE VIII.

\begin{tabular}{|c|c|c|c|c|c|c|c|c|c|c|c|c|}
\hline & \multicolumn{2}{|c|}{$\begin{array}{c}\text { Beries } 33 . \\
\text { 24-Hours } \\
\text { B. coli Agar } \\
\text { Suspension. }\end{array}$} & \multicolumn{2}{|c|}{$\begin{array}{c}\text { Series 34. } \\
\text { 24-Hours B. coli } \\
\text { Agar } \\
\text { Suspension. }\end{array}$} & \multicolumn{2}{|c|}{$\begin{array}{c}\text { Series } 35 . \\
\text { 24-Hours B. coli } \\
\text { Agar Suspension. }\end{array}$} & \multicolumn{2}{|c|}{$\begin{array}{c}\text { Beries 86. } \\
\text { 24-Hours B. coli } \\
\text { Agar Suspension. }\end{array}$} & \multicolumn{2}{|c|}{$\begin{array}{c}\text { Series 37. } \\
\text { 24-Hours B. coli } \\
\text { Agar Suspension. }\end{array}$} \\
\hline & & & A.A. & $\begin{array}{l}\text { R.A. } \\
(0.001 \\
=1) .\end{array}$ & $\begin{array}{l}\text { A.A. } \\
\text { c.c. }\end{array}$ & $\begin{array}{l}\text { R.A. } \\
\left(0^{\circ} 001\right. \\
=1)\end{array}$ & $\begin{array}{l}\text { A.A. } \\
\text { c.c. }\end{array}$ & $\begin{array}{l}\text { R.A. } \\
\left(0^{\circ} 0009\right. \\
=1)\end{array}$ & A.A. & $\begin{array}{l}\text { R.A. } \\
(0.0009 \\
=1) .\end{array}$ & $\begin{array}{l}\text { A.A. } \\
\text { c.o. }\end{array}$ & $\begin{array}{l}\text { R.A. } \\
(0.00085 \\
=1) .\end{array}$ \\
\hline \multirow{2}{*}{\multicolumn{3}{|c|}{$\begin{array}{l}\text { Culture- } \\
\text { Unheated. }\end{array}$}} & & & & & & & & & & \\
\hline & & & 0.001 & $1 \cdot 0$ & 0.001 & $1 \cdot 0$ & 0.0009 & $1 \cdot 0$ & 0.0009 & 1.0 & 0.00085 & 1.0 \\
\hline \multicolumn{3}{|c|}{ Heated to $70^{\circ} 1 \mathrm{~min}$. } & 0.005 & $5 \cdot 0$ & 0.0074 & $7 \cdot 4$ & 0.0074 & $8 \cdot 2$ & 0.006 & $6 \cdot 67$ & 0.007 & $8 \cdot 2$ \\
\hline ," & " 3 & " & 0.005 & $5 \cdot 0$ & 0.0076 & $7 \cdot 6$ & 0.007 & $7 \cdot 8$ & 0.01 & $11 \cdot 1$ & 0.008 & $9 \cdot 4$ \\
\hline$"$ & , 10 & $"$ & 0.01 & $10 \cdot 0$ & 0.04 & 40.0 & 0.032 & $35 \cdot 6$ & $\begin{array}{c}0.01 \\
<0.001\end{array}$ & $\sum_{<1}^{11 \cdot 1}$ & 0.007 & $8 \cdot 2$ \\
\hline$"$ & , 22 & $"$ & 0.011 & $11 \cdot 0$ & $>0.04$ & $\geq 40.0$ & 0.064 & $71 \cdot 1$ & $\begin{array}{l}0.0091 \\
0.005 \\
<0.001\end{array}$ & $\begin{array}{r}10 \cdot 0 \\
5 \cdot 5 \\
1 \cdot 1\end{array}$ & 0.013 & $15 \cdot 3$ \\
\hline$n$ & "38 & $"$ & 0.012 & $12 \cdot 0$ & $>0.04$ & $>40.0$ & $\mid \begin{array}{c}0.09 \\
<0.001\end{array}$ & $\begin{array}{l}100 \cdot 0 \\
<1 \cdot 1\end{array}$ & $\begin{array}{l}0.01 \\
0.005 \\
<0.001\end{array}$ & $\begin{array}{r}11 \cdot 1 \\
5 \cdot 5 \\
<1 \cdot 1\end{array}$ & 0.009 & 10.6 \\
\hline$"$ & "75 & " & 0.015 & 150 & $>0.04$ & $>40.0$ & $\begin{array}{c}0.09 \\
<0.001\end{array}$ & $\begin{array}{l}100 \cdot 0 \\
<1 \cdot 1\end{array}$ & $\begin{array}{r}0.009 \\
<0.001\end{array}$ & $\begin{array}{l}10 \cdot 0 \\
<1 \cdot 1\end{array}$ & 0.007 & $8 \cdot 2$ \\
\hline
\end{tabular}

1 See the explanation preceding Table J.

3-Jh. of PATH,- - vou. xl. 
Table IX.

\begin{tabular}{|c|c|c|c|c|c|c|c|c|c|c|c|}
\hline & \multicolumn{2}{|c|}{$\begin{array}{c}\text { Series 88. } \\
\text { 24-Hours B. coli } \\
\text { Bouillon Culture. }\end{array}$} & \multicolumn{2}{|c|}{$\begin{array}{c}\text { Series } 39 . \\
\text { 24-Hours B.coli } \\
\text { Bouillon Culture. }\end{array}$} & \multicolumn{2}{|c|}{$\mid$\begin{tabular}{c|} 
Berieg 40. \\
94-Hours $B$. coli \\
Bouillon Culture.
\end{tabular}} & \multicolumn{2}{|c|}{$\begin{array}{l}\text { Series 41. } \\
\text { 24-Hours B. coli } \\
\text { Bouillion Culture. }\end{array}$} & \multicolumn{2}{|c|}{$\begin{array}{l}\text { Series } 42 . \\
\text { 24-Hours } B \text {. coll } \\
\text { Bouillon Cuiture. }\end{array}$} \\
\hline & & $\begin{array}{l}\text { A.A. } \\
\text { c.c. }\end{array}$ & $\begin{array}{l}\text { R.A. } \\
\left(0^{\circ} 001\right. \\
=1) .\end{array}$ & $\begin{array}{l}\text { A.A. } \\
\text { c.c. }\end{array}$ & $\begin{array}{l}\text { R.A. } \\
(0.00085 \\
=1)\end{array}$ & $\begin{array}{l}\text { A.A. } \\
\text { c.c. }\end{array}$ & $\begin{array}{l}\text { R.A. } \\
(0.001 \\
=1)\end{array}$ & $\begin{array}{l}\text { A.A. } \\
\text { c.c. }\end{array}$ & $\begin{array}{l}\text { R.A. } \\
\left(0^{-0} 00085\right. \\
=1) .\end{array}$ & $\begin{array}{l}\text { A.A. } \\
\text { c.C. }\end{array}$ & $\begin{array}{l}\text { R.A. } \\
\left(0^{\circ} 00065\right. \\
=1) .\end{array}$ \\
\hline \multicolumn{2}{|l|}{ Culture- } & & & & & & & & & & \\
\hline $\begin{array}{c}\text { Unheate } \\
\text { Heated } \\
\text { ", } \\
\text { ", } \\
\text { ", }\end{array}$ & 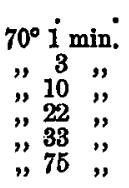 & $\begin{array}{l}0.001 \\
0.0023 \\
0.0022 \\
0.0024 \\
0.0022 \\
0.0019 \\
0.0022\end{array}$ & $\begin{array}{l}1 \cdot 0 \\
2 \cdot 3 \\
2 \cdot 2 \\
2 \cdot 4 \\
2 \cdot 2 \\
1 \cdot 9 \\
2 \cdot 2\end{array}$ & $\begin{array}{l}0.00085 \\
0.004 \\
0.008 \\
0.0075 \\
0.008 \\
0.0075 \\
0.008\end{array}$ & $\begin{array}{l}1 \cdot 0 \\
4 \cdot 7 \\
9 \cdot 4 \\
8 \cdot 8 \\
9 \cdot 4 \\
8 \cdot 8 \\
9 \cdot 4\end{array}$ & $\begin{array}{l}0.001 \\
0.0016 \\
0.007 \\
0.007 \\
0.0075 \\
0.008 \\
0.01\end{array}$ & $\begin{array}{r}1 \cdot 0 \\
1 \cdot 6 \\
7 \cdot 0 \\
7 \cdot 0 \\
7 \cdot 5 \\
8 \cdot 0 \\
10.0\end{array}$ & $\begin{array}{l}0.00085 \\
0.0074 \\
0.007 \\
0.0074 \\
0.0076 \\
0.0068 \\
0.007\end{array}$ & $\begin{array}{l}1 \cdot 0 \\
8 \cdot 7 \\
8 \cdot 2 \\
8 \cdot 7 \\
8 \cdot 9 \\
8 \cdot 0 \\
8 \cdot 2\end{array}$ & $\begin{array}{l}0.00065 \\
0.0034 \\
0.008 \\
0.007 \\
0.007 \\
0.007 \\
0.0084\end{array}$ & $\begin{array}{c}1.0 \\
5 \cdot 23 \\
12 \cdot 3 \\
10.8 \\
10.8 \\
10.8 \\
12.9\end{array}$ \\
\hline
\end{tabular}

TABLE $X$.

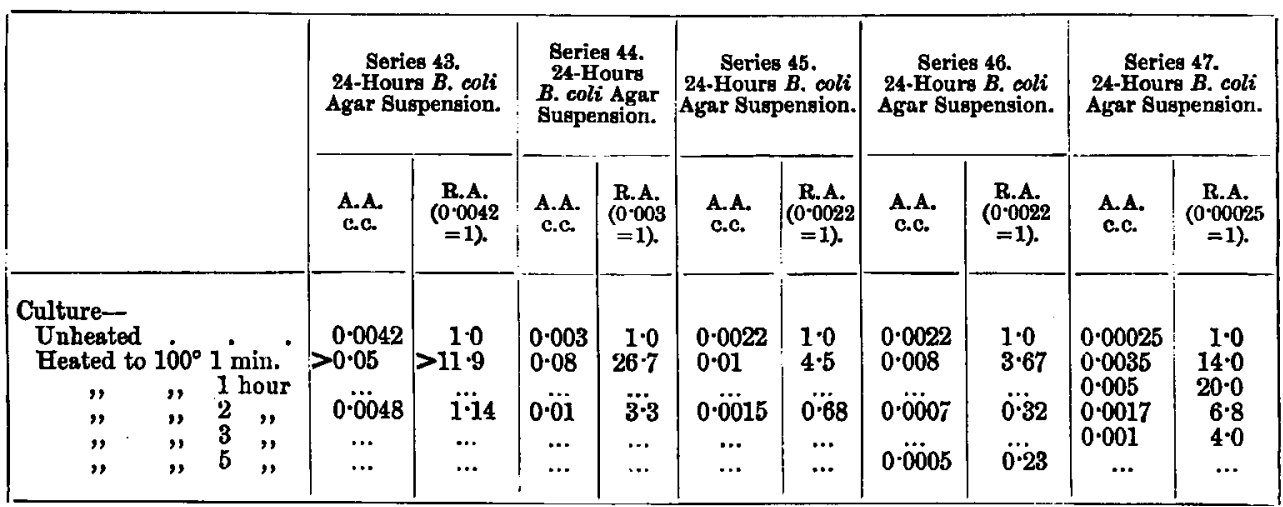

TABLE XI.

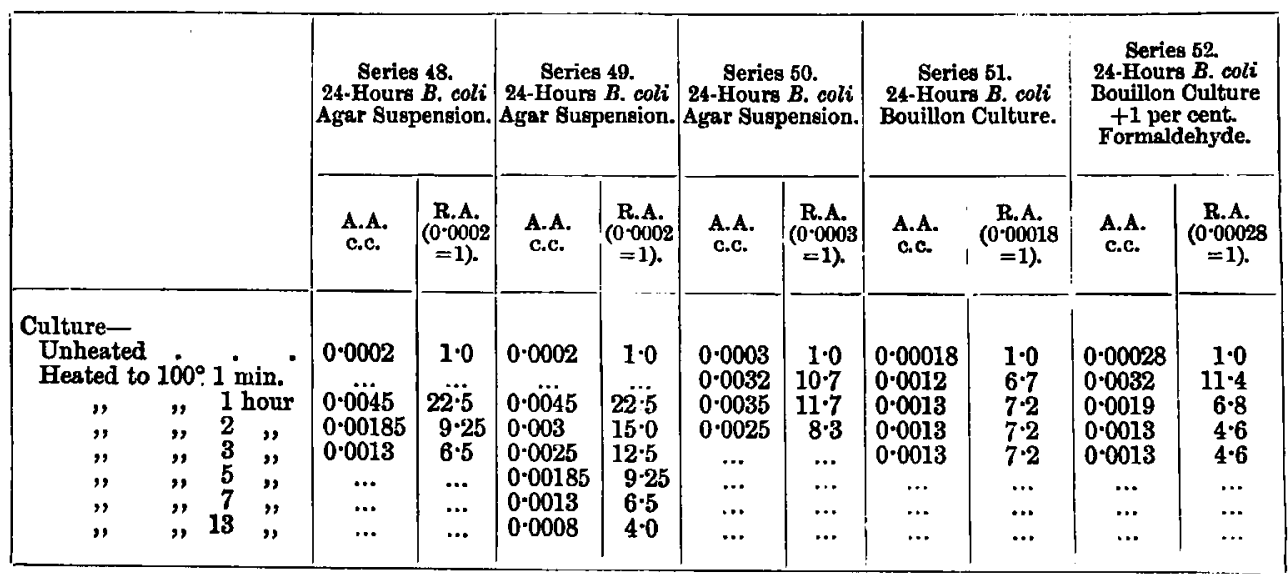


TABLE XII.

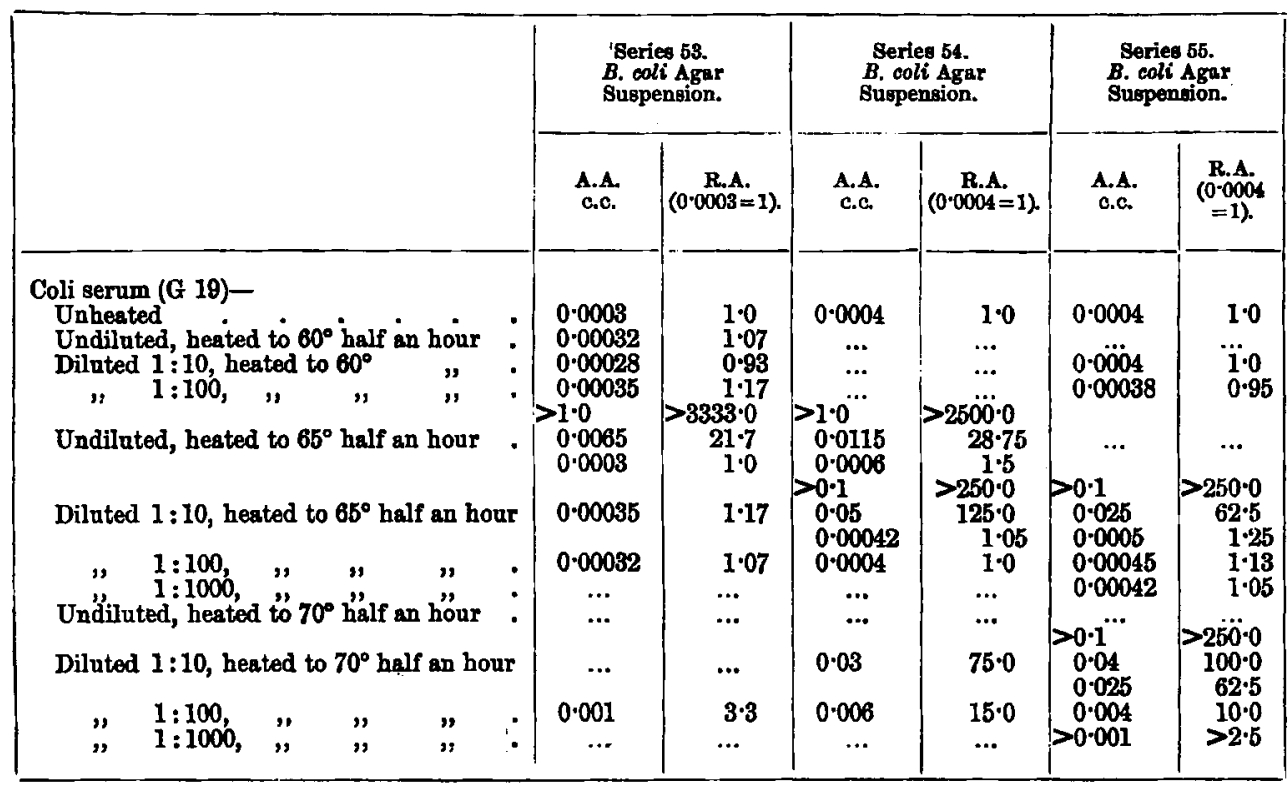

TABLE XIII.

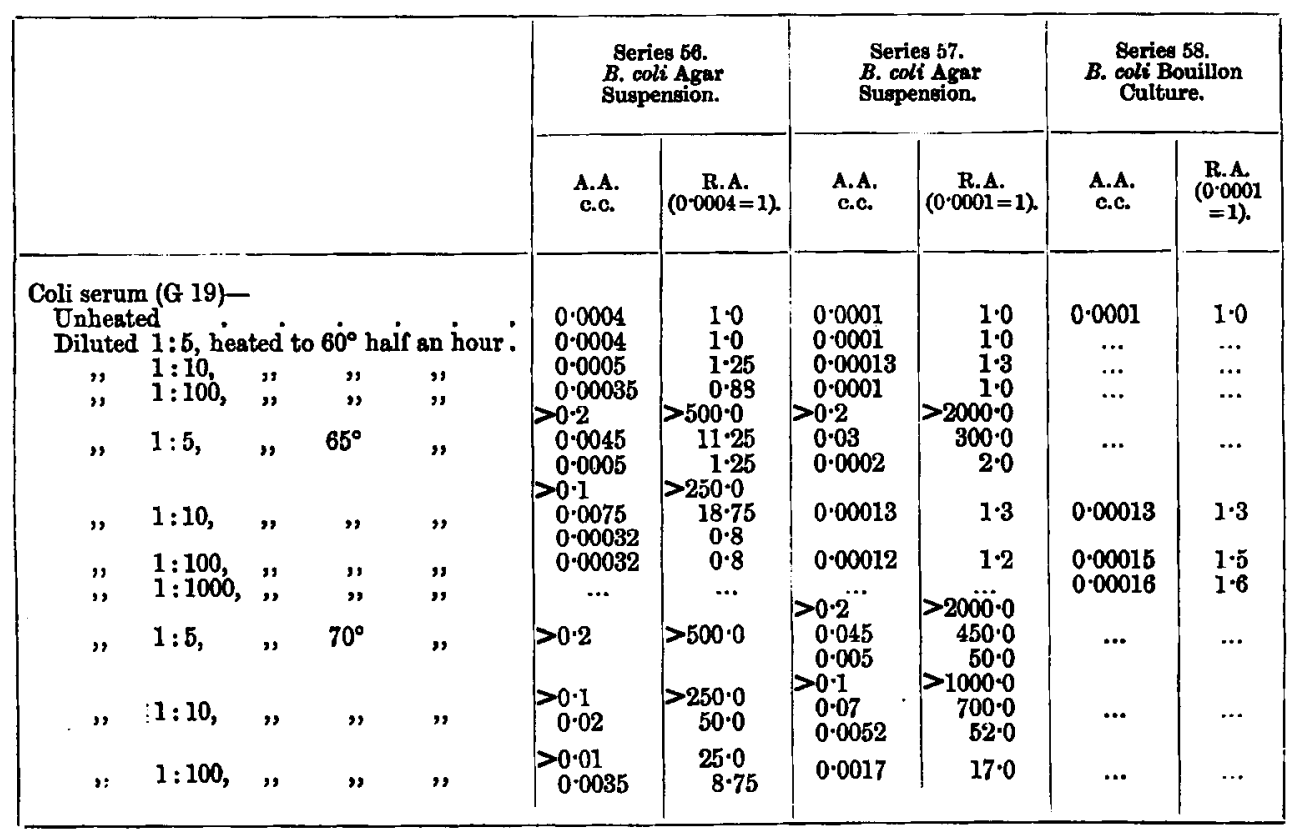


GEORGES DREYER AND A. J. JEX-BLAKE.
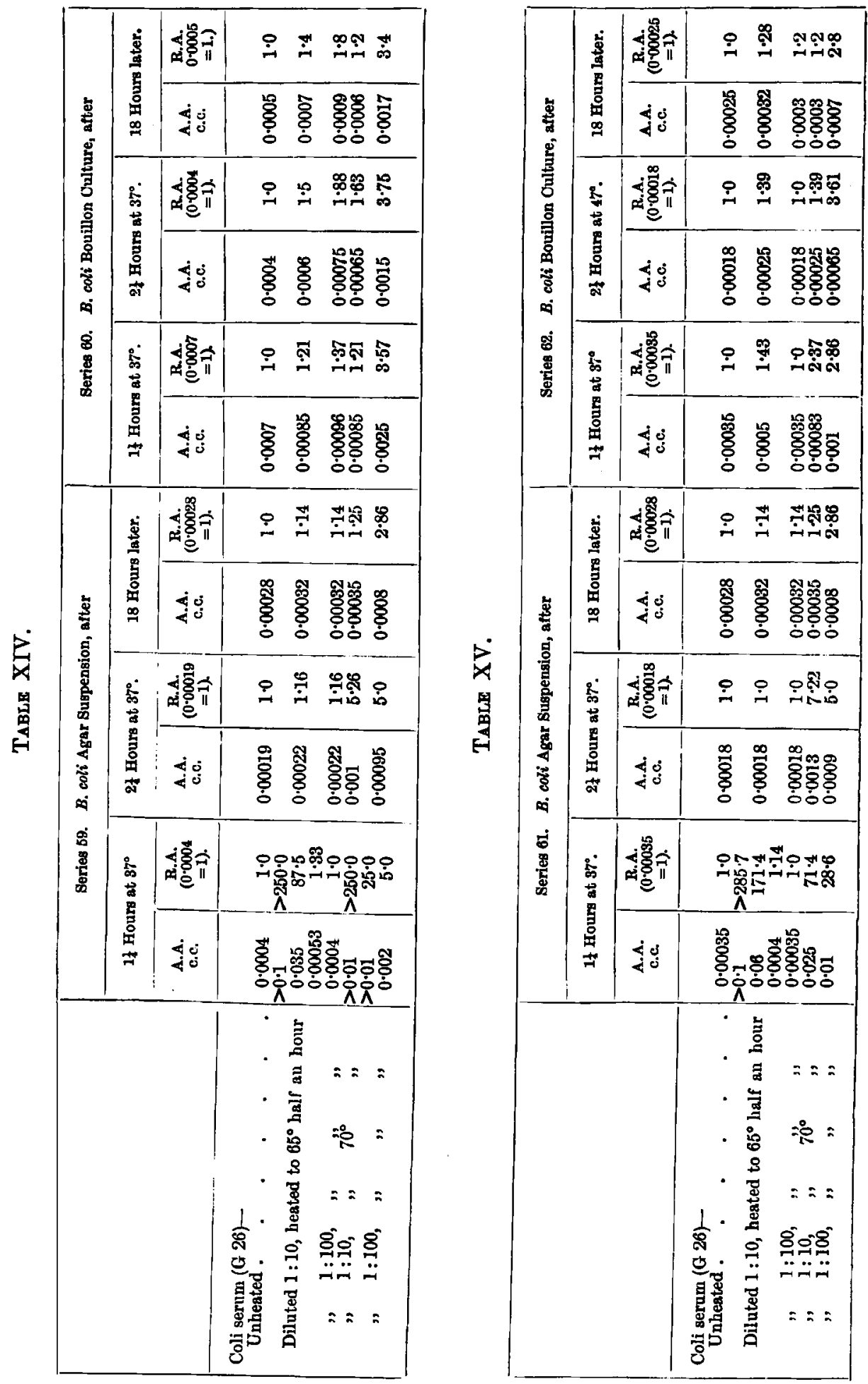
ON THE AGGLUTINATION OF BACTERIA.

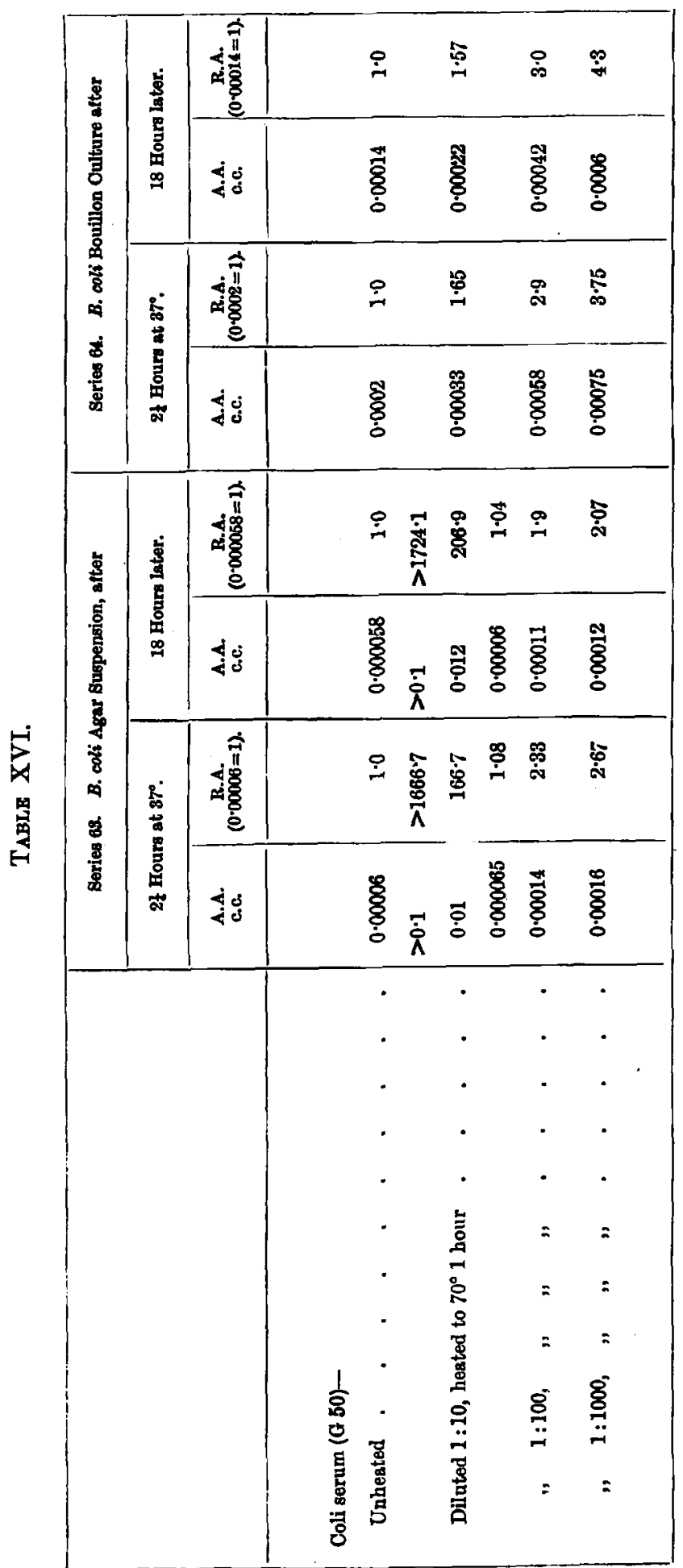




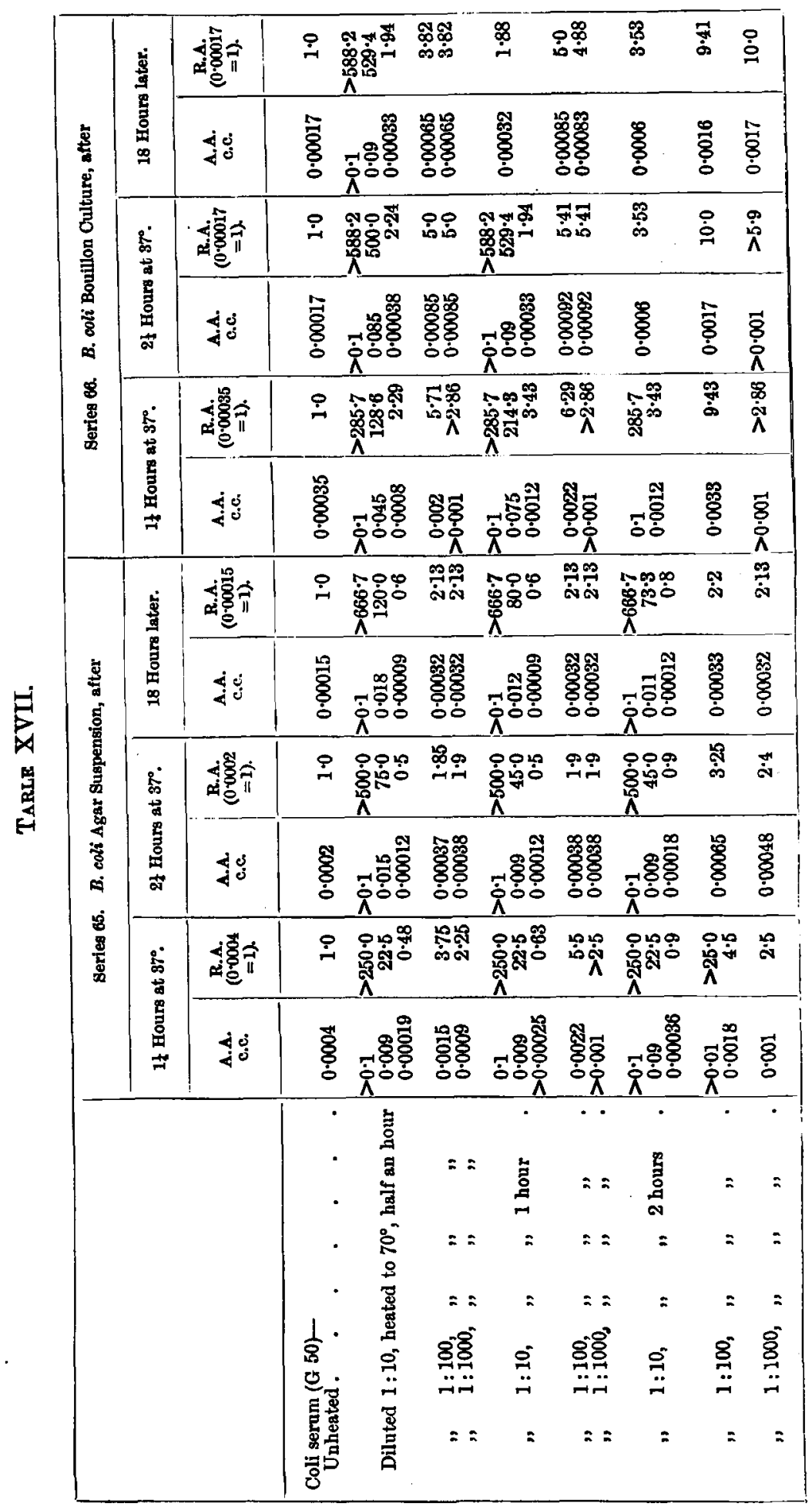


Tabue XVIII.

\begin{tabular}{|c|c|c|c|c|c|c|c|}
\hline & \multicolumn{6}{|c|}{ Series 67. B. coli Agar Surpenaion, after } \\
\hline & & \multicolumn{2}{|c|}{ 1t Hours at $37^{\circ}$. } & \multicolumn{2}{|c|}{ If Hours at $37^{\circ}$. } & \multicolumn{2}{|c|}{18 Hours inter. } \\
\hline & & $\begin{array}{l}\text { A.A. } \\
\text { c.c. }\end{array}$ & $\begin{array}{l}\text { R.A. } \\
(0.00016 \\
=1)\end{array}$ & A.A. & $\begin{array}{l}\text { R.A. } \\
(0.00012 \\
=1)\end{array}$ & $\begin{array}{l}\text { A.A. } \\
\text { c.c. }\end{array}$ & $\begin{array}{l}\text { R.A. } \\
(0.00012 \\
=1)\end{array}$ \\
\hline \multicolumn{2}{|c|}{$\begin{array}{l}\text { Coli serum (G 50)- } \\
\text { Diluted with normal saline, unheated. }\end{array}$} & 0.00016 & $1 \cdot 0$ & 0.00012 & $1 \cdot 0$ & 0.00011 & $1 \cdot 0$ \\
\hline$"$, & $\begin{array}{l}1: 10 \text { with normual saline, hested to } \\
70^{\circ} 1 \text { hour. }\end{array}$ & $\begin{array}{l}>0.1 \\
0.015 \\
0.00012\end{array}$ & $\begin{array}{c}>625 \cdot 0 \\
93 \cdot 8 \\
0.75\end{array}$ & $\begin{array}{l}>0.1 \\
0.018 \\
0.00006\end{array}$ & $\begin{array}{r}>833.3 \\
150.0 \\
0.5\end{array}$ & $\begin{array}{l}>0.1 \\
0.023 \\
0.000054\end{array}$ & $\begin{array}{c}>909.1 \\
209 \cdot 1 \\
0.49\end{array}$ \\
\hline$"$ & $\begin{array}{c}1: 100 \text { with normal saline, hested to } \\
70^{\circ} 1 \text { hour. }\end{array}$ & 0.00083 & $2 \cdot 06$ & 0.00016 & $1 \cdot 33$ & 0.00014 & $1 \cdot 27$ \\
\hline ", & $\begin{array}{c}1: 1000 \text { with normal saline, heated } \\
\text { to } 70^{\circ} 1 \text { hour. }\end{array}$ & 0.00057 & $3 \cdot 56$ & 0.00029 & $2 \cdot 42$ & 0.00026 & $2 \cdot 36$ \\
\hline & $\begin{array}{l}\text { with } 10 \text { per cent. normal loorse } \\
\text { serum, unheated. }\end{array}$ & 0.00011 & 0.69 & 0.00008 & 0.67 & 0.00007 & 0.64 \\
\hline$"$ & $\begin{array}{l}1: 10 \text { with } 10 \text { per cent. normal horse } \\
\text { serum, heated to } 70^{\circ} 1 \text { hour. }\end{array}$ & $\begin{array}{l}>0.1 \\
0.007 \\
0.00015\end{array}$ & $\begin{array}{r}>625.0 \\
41.3 \\
0.94\end{array}$ & $\begin{array}{l}>0.1 \\
0.0085 \\
0.000075\end{array}$ & $\begin{array}{r}>833 \cdot 8 \\
70.8 \\
0.63\end{array}$ & $\begin{array}{l}>0.1 \\
0.01 \\
\quad \ldots\end{array}$ & $\begin{array}{c}>909.1 \\
90.9 \\
\cdots\end{array}$ \\
\hline$"$ & $\begin{array}{l}\text { I : } 100 \text { with } 10 \text { per cent. normal horse } \\
\text { serun, heated to } 70^{\circ} 1 \text { hour. }\end{array}$ & 0.00185 & $11 \cdot 56$ & 0.0009 & $7 \cdot 5$ & 0.00023 & 2.09 \\
\hline \multirow[t]{4}{*}{ " } & $\begin{array}{c}1: 1000 \text { with } 10 \text { per cent. normal horse } \\
\text { serum, heated to } 70^{\circ} 1 \text { hour. }\end{array}$ & 0.0014 & $8 \cdot 75$ & 0.00075 & 6.25 & 0.00032 & $2 \cdot 91$ \\
\hline & & \multicolumn{6}{|c|}{ Series 68. B. coli Bouillon Culture, after } \\
\hline & & \multicolumn{2}{|c|}{17 Hours at $37^{\circ}$. } & \multicolumn{2}{|c|}{21 Hours at $87^{\circ}$. } & \multicolumn{2}{|c|}{18 Hours later. } \\
\hline & & $\begin{array}{l}\text { A.A. } \\
\text { c.c. }\end{array}$ & $\begin{array}{l}\text { R.A. } \\
(0 \cdot 00022 \\
=1)\end{array}$ & $\begin{array}{l}\text { A.A. } \\
\text { a.c. }\end{array}$ & $\begin{array}{l}\text { R.A. } \\
(0.00014 \\
=1)\end{array}$ & $\begin{array}{l}\text { A.A. } \\
\text { c.c. }\end{array}$ & $\begin{array}{c}\text { R.A. } \\
(0.00014 \\
=1)\end{array}$ \\
\hline \multicolumn{2}{|c|}{ Coli serum (G 50)- } & 0.00022 & $1 \cdot 0$ & 0.00014 & 1.0 & 0.00014 & $1 \cdot 0$ \\
\hline " & $\begin{array}{l}\text { I: } 10 \text { with normal saline, heated to } \\
70^{\circ} 1 \text { hour. }\end{array}$ & 0.0004 & 1.82 & 0.00024 & $1 \cdot 71$ & 0.00023 & 164 \\
\hline ,: & $\begin{array}{l}1: 100 \text { with normal saline, heated to } \\
70^{\circ} 1 \text { hour. }\end{array}$ & 0.0009 & 4.09 & 0.00055 & 3.93 & 0.00054 & $3 \cdot 86$ \\
\hline$"$ & $\begin{array}{c}1: 1000 \text { with normal saline, heated } \\
70^{\circ} 1 \text { hour. }\end{array}$ & $>0.001$ & $>4.55$ & $>0.001$ & $>7 \cdot 14$ & 0.0011 & $7 \cdot 86$ \\
\hline " & $\begin{array}{l}\text { with } 10 \text { per cent. normal horse } \\
\text { serum, unheated. }\end{array}$ & 0.00025 & $1 \cdot 14$ & 0.00018 & 0.98 & 0.00011 & 0.79 \\
\hline ", & $\begin{array}{c}1: 10 \text { with } 10 \text { per cent. normal horse } \\
\text { serum, heated to } 70^{\circ} 1 \text { hour. }\end{array}$ & $\begin{array}{l}>0.1 \\
0.022 \\
0.0012\end{array}$ & $\left.\mid \begin{array}{c}-454.5 \\
100 \cdot 0 \\
5.45\end{array}\right]$ & $\begin{array}{l}>0.1 \\
0.097 \\
0.00033\end{array}$ & \begin{tabular}{|}
$>714 \cdot 3$ \\
$284 \cdot 3$ \\
$2 \cdot 36$
\end{tabular} & $\begin{array}{l}>0.1 \\
0.045 \\
0.00027\end{array}$ & $\begin{array}{r}>714.3 \\
321.4 \\
1.93\end{array}$ \\
\hline$"$ & $\begin{array}{l}1: 100 \text { with } 10 \text { per cent. norrnal horse } \\
\text { serum, heated to } 70^{\circ} 1 \text { hour. }\end{array}$ & $>0.01$ & $>45.5$ & 0.0012 & $8 \cdot 57$ & 0.0011 & $7 \cdot 86$ \\
\hline$"$ & $\begin{array}{r}1: 1000 \text { with } 10 \text { per cent. normal horse } \\
\text { serum, heated to } 70^{\circ} 1 \text { hour. }\end{array}$ & $>0.001$ & $>4.55$ & $>0.001$ & $>7 \cdot 14$ & 0.0015 & $10 \cdot 71$ \\
\hline
\end{tabular}




\section{TABLE XIX.}

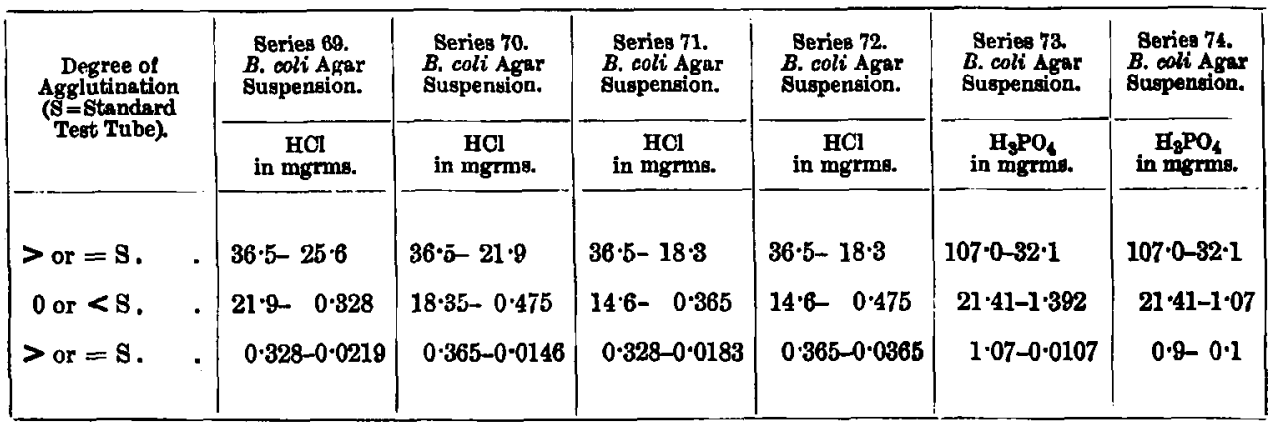

Tabla XX.

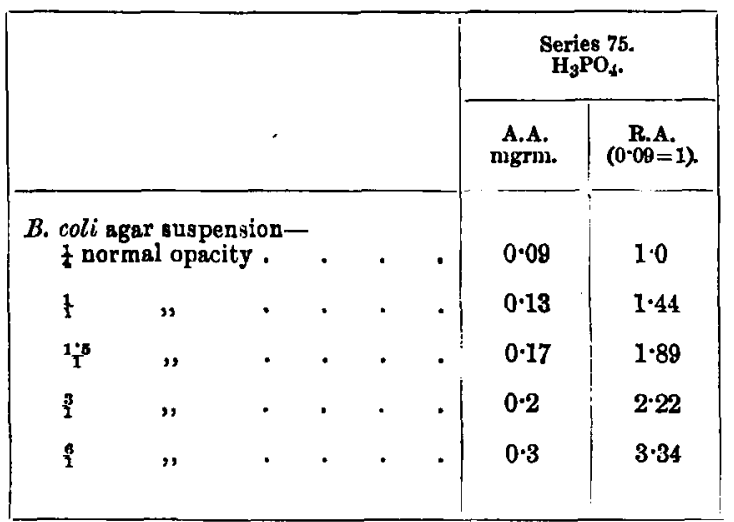

TABLE XXI.

\begin{tabular}{|c|c|c|c|c|c|c|c|c|}
\hline \multirow{3}{*}{$\begin{array}{l}\text { Degree of } \\
\text { Agglutina- } \\
\text { tion ( } \mathbf{S =} \\
\text { Standard } \\
\text { Test Tube). }\end{array}$} & \multicolumn{8}{|c|}{ Series 76. B. coli Agar Suspension in Normal Saline. } \\
\hline & Unheated. & $\begin{array}{l}\text { Heated to } \\
50^{\circ} \text {. }\end{array}$ & $\begin{array}{l}\text { Heated to } \\
60^{\circ} \text {. }\end{array}$ & $\begin{array}{c}\text { Heated to } \\
70^{\circ} \text {. }\end{array}$ & $\begin{array}{l}\text { Heated to } \\
80^{\circ} \text {. }\end{array}$ & $\begin{array}{l}\text { Heated to } \\
90^{\circ} .\end{array}$ & $\begin{array}{c}\text { Heated to } \\
100^{\circ} .\end{array}$ & $\begin{array}{l}\text { Heated to } \\
100^{\circ} 1 \mathrm{hr} .\end{array}$ \\
\hline & $\underset{\text { in imgrms. }}{\mathrm{H}_{3} \mathrm{PO}_{4}}$ & $\underset{\text { in mgrms. }}{\mathbf{H}_{\mathbf{3}} \mathbf{P O}_{\mathbf{4}}}$ & $\underset{\text { in mgrms. }}{\mathbf{H}_{\mathbf{3}} \mathbf{P O}_{\mathbf{4}}}$ & $\underset{\text { in mgrms. }}{\mathrm{H}_{\mathbf{3}} \mathrm{PO}_{\mathbf{4}}}$ & $\underset{\text { in mgrmes. }}{\mathrm{HP}_{\mathbf{9}} \mathbf{O}_{\mathbf{4}}}$ & $\begin{array}{c}\mathrm{H}_{\mathbf{3}} \mathrm{PO}_{\mathbf{4}} \\
\text { in motms. }\end{array}$ & $\mid \begin{array}{c}\mathbf{B}_{\mathbf{3}} \mathbf{P O}_{\mathbf{4}} \\
\text { in mgrms. }\end{array}$ & $\underset{\text { in mgrms. }}{\mathrm{H}_{4} \mathrm{PO}_{4}}$ \\
\hline$>$ or $=\mathrm{S}$ & $107 \cdot 0-21 \cdot 4$ & $107 \cdot 0-32 \cdot 1$ & $107 \cdot 0-42 \cdot 8$ & $107 \cdot 0-53 \cdot 6$ & $107 \cdot 0-64 \cdot 3$ & $107 \cdot 0-64 \cdot 3$ & $107 \cdot 0-85 \cdot 7$ & $107 \cdot 0-96 \cdot 3$ \\
\hline 0 or $<\mathrm{s}$ & $18 \cdot 2-0.749$ & $21 \cdot 4-0 \cdot 643$ & $32 \cdot 1-0.643$ & $42 \cdot 8-0.643$ & $3|53 \cdot 6-1 \cdot 819|$ & $53 \cdot 6-1 \cdot 819$ & $\cdots$ & $\ldots$ \\
\hline$>$ or $=\mathrm{S}$ & $0.643-0.0963$ & $0.536-0.1$ & $0.536-0.11$ & $0.536-0.139$ & $\cdots$ & $\ldots$ & $\ldots$ & $\cdots$ \\
\hline
\end{tabular}


TABLe XXII.

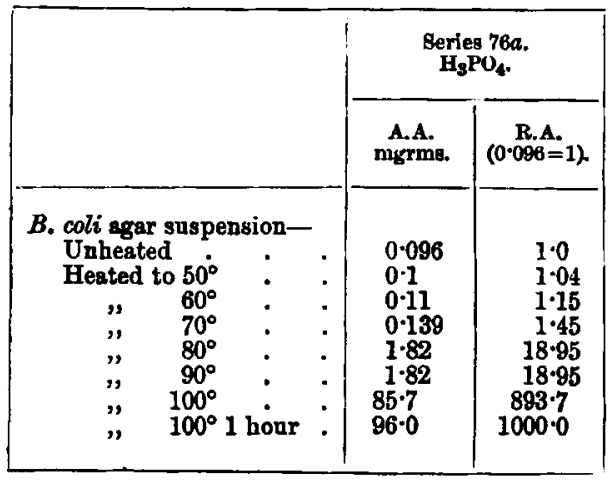

TABLE XXIII.

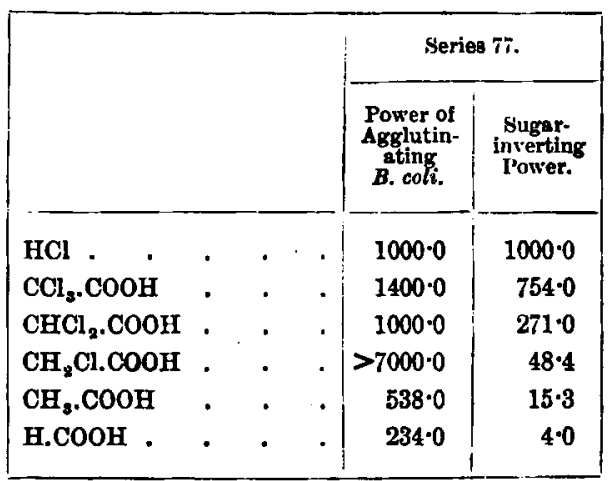

TABLE XXIV.

\begin{tabular}{|c|c|c|c|c|c|c|c|}
\hline \multicolumn{8}{|c|}{ Series 78. B. coli Agar Suspension in Normal Saline. } \\
\hline \multicolumn{2}{|c|}{$\begin{array}{c}\text { A. } \\
\text { Alone. }\end{array}$} & \multicolumn{2}{|c|}{$\begin{array}{l}\text { B. } \\
+1 \text { per cent. Normal } \\
\text { Horse Serum. }\end{array}$} & \multicolumn{2}{|c|}{$\begin{array}{l}\text { C. } \\
\text { +0.1 per cent. Normal } \\
\text { Horse Berum. }\end{array}$} & \multicolumn{2}{|c|}{$\begin{array}{l}\text { D. } \\
\text { +0.01 per cent. Normal } \\
\text { Horse Serum. }\end{array}$} \\
\hline HCl in mgrnss. & $\begin{array}{l}\text { Degree of } \\
\text { Agrlutin- } \\
\text { ation (S= } \\
\text { Standard). }\end{array}$ & $\begin{array}{c}\mathrm{HCl} \text { in } \\
\text { mgrnas. }\end{array}$ & $\begin{array}{l}\text { Degree of } \\
\text { Agglutin- } \\
\text { atton }(\$=) \\
\text { Standard). }\end{array}$ & $\begin{array}{c}\text { HCl in } \\
\text { mgrms. }\end{array}$ & $\begin{array}{l}\text { Degree of } \\
\text { Agglutin- } \\
\text { otion (8 = } \\
\text { Btandard). }\end{array}$ & $\begin{array}{l}\text { HOl in } \\
\text { ngrus. }\end{array}$ & $\begin{array}{l}\text { Degree of } \\
\text { Agglutin- } \\
\text { ation ( } \mathbf{S}= \\
\text { Standard). }\end{array}$ \\
\hline $\begin{array}{l}3 \cdot 65-0.73 \\
0.6205-0.0621 \\
0.04745\end{array}$ & $\begin{array}{c}0 \text { or }<\mathrm{S} \\
>\text { or }=\mathrm{S} \\
0\end{array}$ & $\mid \begin{array}{c}3.65-0.4745 \\
0.365-0 \cdot 1095 \\
0.09125\end{array}$ & $\underset{\substack{0 \\
0}}{\text { or }}=\mathrm{s}$ & $\left|\begin{array}{c}3 \cdot 65-0.4745 \\
0.365-0.073 \\
0.06205\end{array}\right|$ & $\underset{0}{\text { or }}=\mathrm{s}$ & $\begin{array}{c}3 \cdot 65-2 \cdot 19 \\
1 \cdot 825-0.4745 \\
0.365-0.06205 \\
0 \cdot 04745\end{array}$ & $\begin{array}{l}=\underset{0}{\operatorname{or}<\mathrm{S}} \\
>\underset{0}{\text { or }}=\mathrm{s} \\
0\end{array}$ \\
\hline
\end{tabular}

TABLE XXV.

\begin{tabular}{|c|c|c|c|c|c|c|c|c|}
\hline & & & \multicolumn{3}{|c|}{$\begin{array}{l}\text { Series } 79 . \\
\text { B. coli Bouillon Culture. }\end{array}$} & \multicolumn{3}{|c|}{$\begin{array}{l}\text { Series } 80 \\
\text { B. coli Bouillon Culture. }\end{array}$} \\
\hline & & & $\begin{array}{l}\text { A.A. } \\
\text { c.c. }\end{array}$ & $\begin{array}{l}\text { R.A. } \\
(0.0004 \\
=1) .\end{array}$ & $\begin{array}{l}\text { HCl in } \\
\text { mgrms. }\end{array}$ & $\begin{array}{l}\text { A.A. } \\
\text { c.c. }\end{array}$ & $\begin{array}{l}\text { R.A. } \\
\left(\begin{array}{l}0.0005 \\
=1) .\end{array}\right.\end{array}$ & $\begin{array}{l}\mathrm{HCl} \text { in } \\
\text { magrmes. }\end{array}$ \\
\hline \multirow{2}{*}{\multicolumn{3}{|c|}{$\begin{array}{l}\text { B. coli sernm (G 26)- } \\
\text { Diluted } 1: 100, \text { without } \mathrm{HCl} \\
+0.077 \mathrm{BCl} \text { per mille }\end{array}$}} & 0.0004 & 1.0 & & 0.0005 & $1 \cdot 0$ & \\
\hline & & & $\begin{array}{l}0.0005 \\
0.0009\end{array}$ & $\begin{array}{l}1 \cdot 25 \\
2 \cdot 28\end{array}$ & $\begin{array}{l}0.0039 \\
0.0107\end{array}$ & 0.0005 & 1.0 & 0.00385 \\
\hline$"$ & $+0 \cdot 186$ & $"$ & 0.0013 & $3 \cdot 25$ & 0.0242 & 0.00095 & 1.9 & 0.01767 \\
\hline ", & $\begin{array}{r}+0.408 \\
+0.408\end{array}$ & ", & $\begin{array}{l}0.0018 \\
0.002\end{array}$ & $\begin{array}{l}4.5 \\
5.0\end{array}$ & $\begin{array}{l}0.0629 \\
0.0816\end{array}$ & 0.0025 & $5 \cdot 0$ & 0.1020 \\
\hline$"$ & +0.641 & $"$ & 0.0027 & $6 \cdot 75$ & 0.1731 & Aïns & & 0 \\
\hline$"$ & $\begin{array}{l}+1.0 \\
+1.558\end{array}$ & $"$ & 0.0055 & $13 \cdot 75$ & 0.55 & $\begin{array}{l}0.006 \\
0.0085\end{array}$ & 17.0 & $\begin{array}{l}0.6 \\
1.326\end{array}$ \\
\hline ,. & $+2 \cdot 439$ & $"$ & $\cdots$ & $\ldots$ & $\ldots$ & 0.0095 & $19 \cdot 0$ & $2 \cdot 3181$ \\
\hline
\end{tabular}


TABLE XXVI.

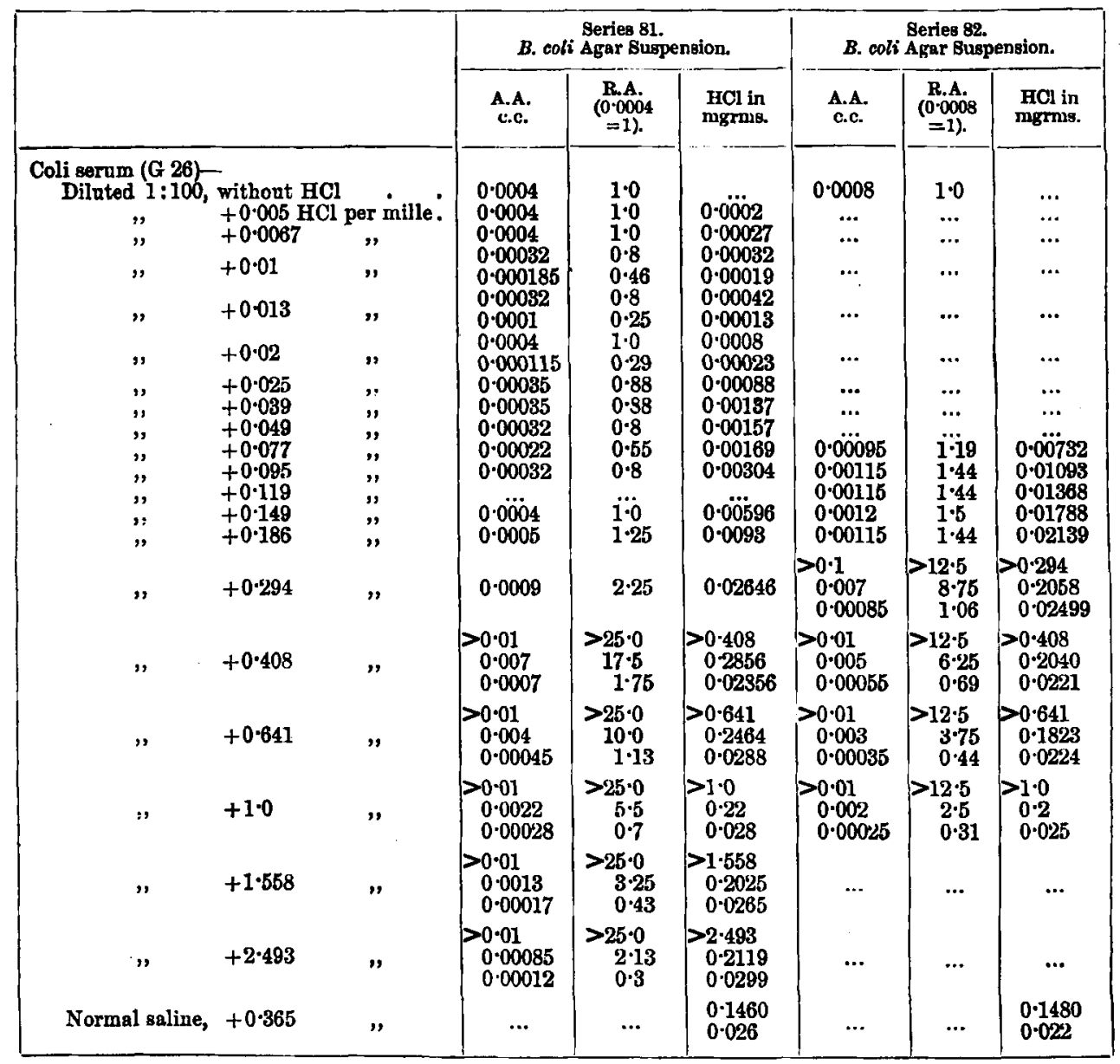

TABLE XXVII.

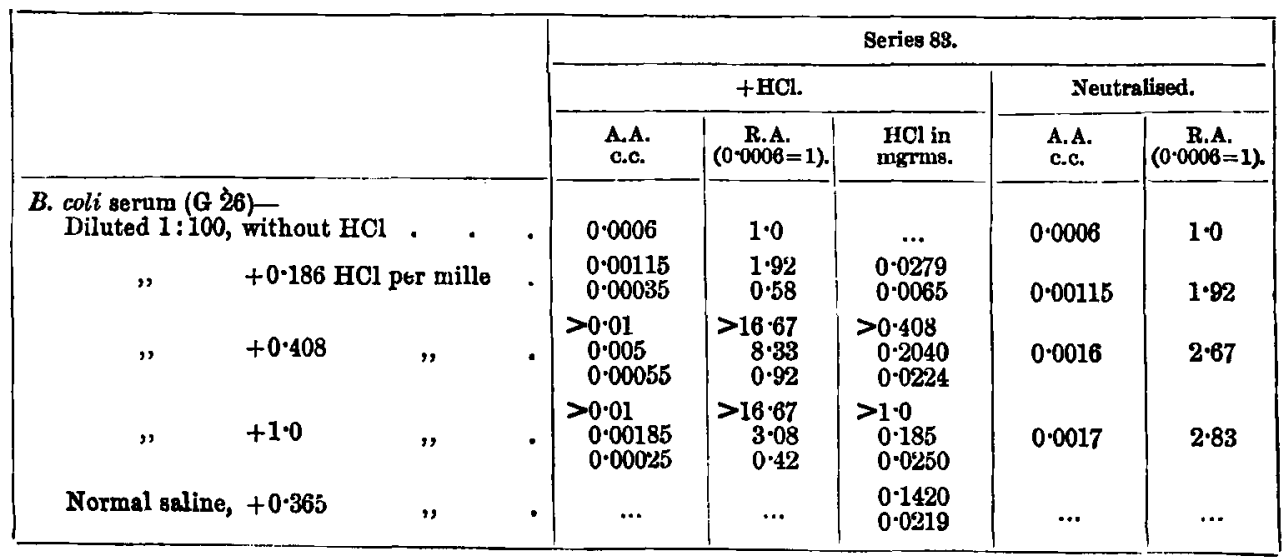


ON THE AGGLUTINATION OF BACTERIA.
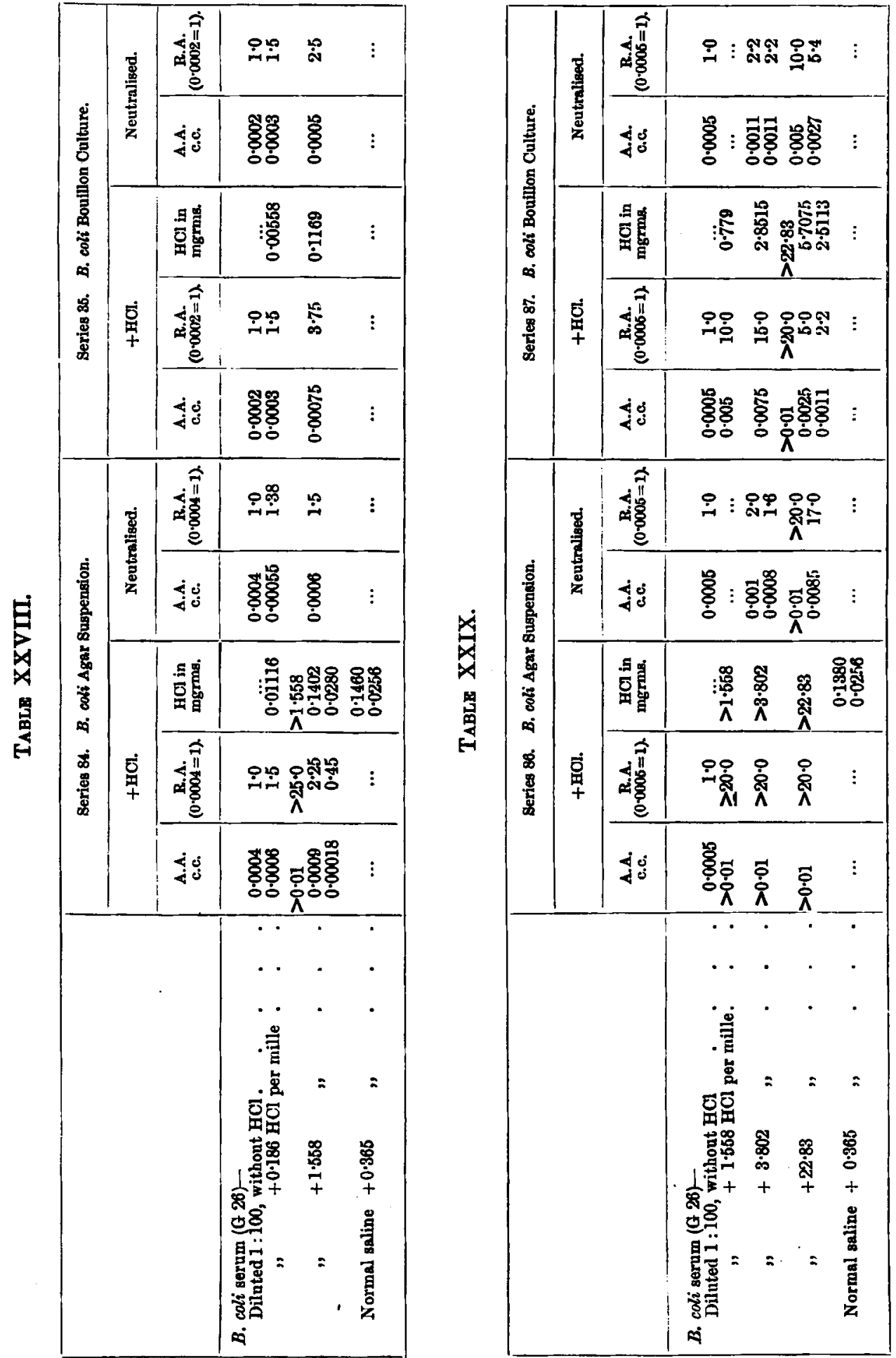
GEORGES DREYER AND A. J. JEX-BLAKE.

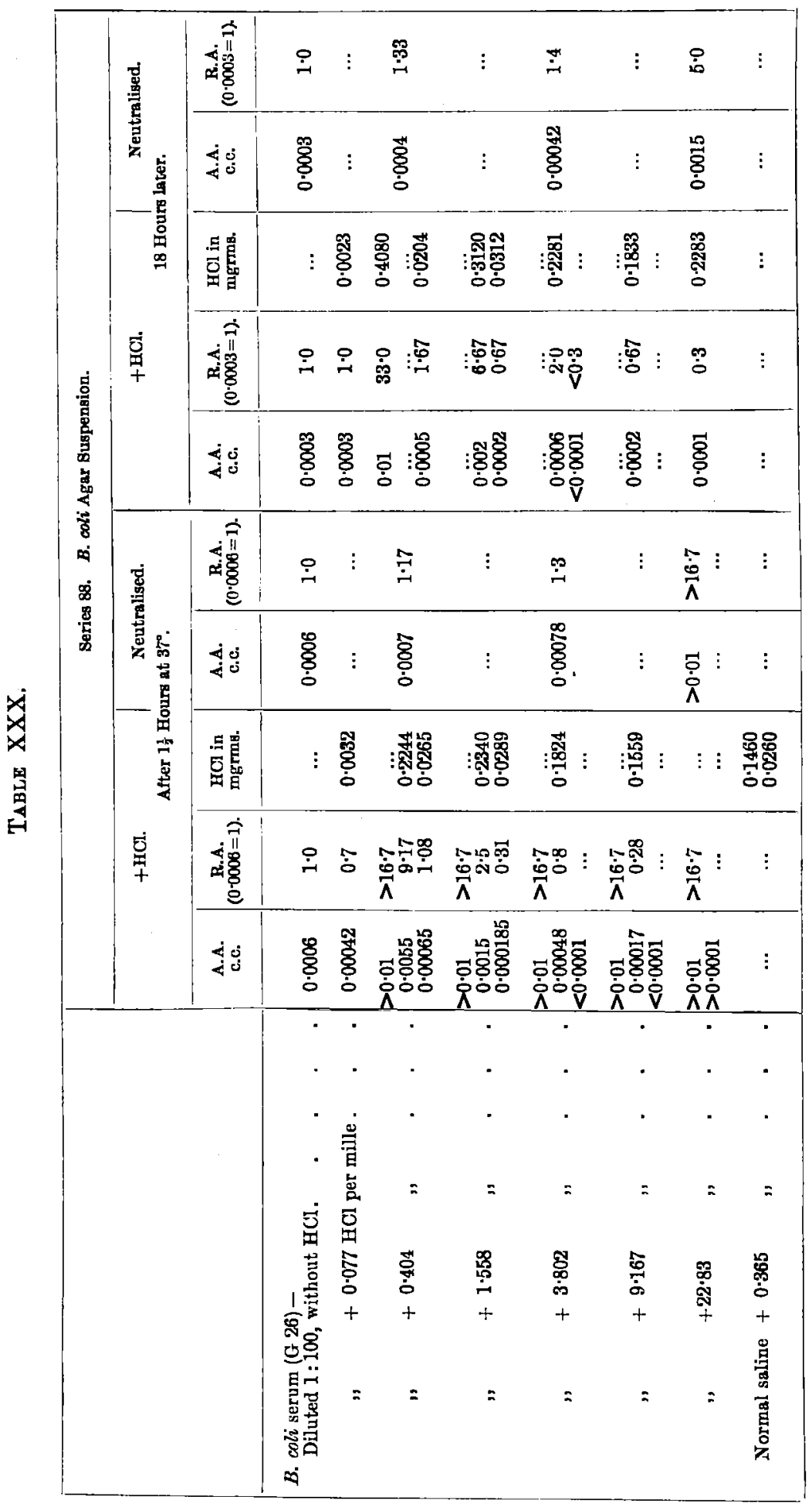


ON THE AGGLUTINATION OF BACTERIA.

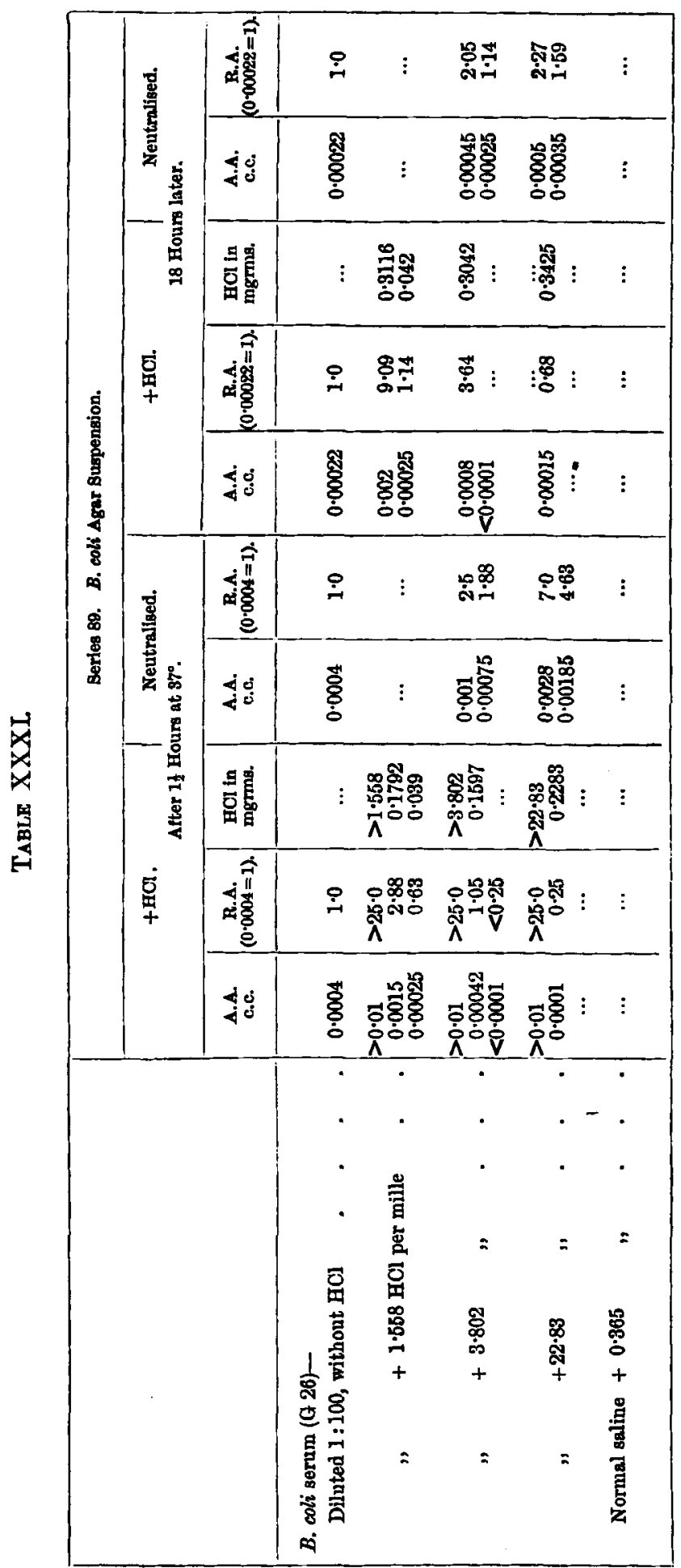


TABLE XXXII.

\begin{tabular}{|c|c|c|c|c|c|c|c|}
\hline & & & & & B. typh & $\begin{array}{l}\text { Series } 90 . \\
\text { sus Agar } \mathrm{Su}\end{array}$ & pension. \\
\hline & & & & & $\begin{array}{l}\text { A.A. } \\
\text { c.c. }\end{array}$ & $\begin{array}{l}\text { R.A. } \\
(0.0028 \\
=1) .\end{array}$ & $\begin{array}{c}\mathrm{HCl} \text { in } \\
\text { mgrms. }\end{array}$ \\
\hline B. typhosus & $\begin{array}{l}m(\mathrm{~T} 14)- \\
\text { without } \mathrm{HC}\end{array}$ & . $\quad \cdot$ & - & .. & 0.0028 & 1.0 & $\ldots$ \\
\hline$"$ & $+0.077 \mathrm{HC}$ & per mille & - & .. & 0.003 & $1 \cdot 1$ & 0.00578 \\
\hline$"$ & $+0 \cdot 186$ & $"$ & - & .. & $\begin{array}{c}>0.04 \\
0.026 \\
0.012\end{array}$ & $\begin{array}{r}>14 \cdot 3 \\
9 \cdot 29 \\
4 \cdot 29\end{array}$ & $\begin{array}{c}>0 \cdot 186 \\
0 \cdot 1209 \\
0 \cdot 0558\end{array}$ \\
\hline$"$ & +0.408 & $"$ & . & . & $\begin{array}{c}>0.04 \\
0.014 \\
0.004\end{array}$ & $\begin{array}{c}>14.3 \\
5 \cdot 0 \\
1 \cdot 43\end{array}$ & $\begin{array}{c}>0 \cdot 408 \\
0 \cdot 1428 \\
0.0408\end{array}$ \\
\hline$"$ & $+1 \cdot 0$ & $"$ & $\cdot$ & . . & $\begin{array}{l}>0.04 \\
0.0074 \\
0.00192\end{array}$ & $\begin{array}{r}>14.3 \\
2 \cdot 64 \\
0.69\end{array}$ & $\begin{array}{c}>1 \cdot 0 \\
0 \cdot 185 \\
0.0408\end{array}$ \\
\hline$"$ & +1.558 & $"$ & • & $\cdot$ & $\begin{array}{l}>0.04 \\
0.0036 \\
0.0014\end{array}$ & $\begin{array}{r}>14.3 \\
2.64 \\
0.69\end{array}$ & $\begin{array}{c}>1 \cdot 558 \\
0 \cdot 1402 \\
0.0545\end{array}$ \\
\hline$"$ & +3.802 & $"$ & . & $\cdot$ & $\begin{array}{l}>0.04 \\
0.00152 \\
0.00068\end{array}$ & $\begin{array}{r}>14.3 \\
0.54 \\
0.24\end{array}$ & $\begin{array}{c}>3.802 \\
0.1445 \\
0.0646\end{array}$ \\
\hline$"$ & $+9 \cdot 167$ & $"$ & $\cdot$ & $\cdot$ & $\begin{array}{l}>0.04 \\
0.00072 \\
0.00044\end{array}$ & $\begin{array}{r}>14.3 \\
0.26 \\
0.16\end{array}$ & $\begin{array}{r}>9 \cdot 167 \\
0 \cdot 1650 \\
0 \cdot 1008\end{array}$ \\
\hline$"$ & $+22 \cdot 83$ & $"$ & $\cdot$ & $\cdot$ & $\begin{array}{c}>0.04 \\
<0.0004 \\
\ldots\end{array}$ & $\begin{array}{c}>14.3 \\
<0.143 \\
\ldots\end{array}$ & $\begin{array}{c}>22 \cdot 83 \\
<0 \cdot 2283 \\
\ldots\end{array}$ \\
\hline Normal s & $0+0.365$ & $"$ & . & 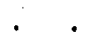 & $\ldots$ & $\ldots$ & $\ldots$ \\
\hline
\end{tabular}

\section{REFERENCES.}

Arrhenius . . . . Ztschr.f.physitial. Chem., Leipzig, 1903, Bd. xlvi. S. 415 .

BaIL . . . . . . . Prag. med. Wchnschr., 1901, Bd. xxvi. S. 85.

Bonder . . . . . Ann. de l'Inst. Pasteur, Paris, 1896, tome x. p. 193 ; ibid., 1900, tome xiv. p. 257.

Bossaert . . . . . . Ibid., 1898, tome xii. p. 857.

Craw . . . . . . . Lancet, London, 1904, vol. i. p. 434.

Dhralle . . . . . Ann. de l'Inst. Pasteur, Paris, 1902, tome xvi. p. 595.

DREYER . . . . . . Brit. Med. Journ., Iondon, 1904, vol. ii. p. 564.

EIsanberg. . . . . . Ztschr. $f$. Hyg. u. Infectionshrankh., Leipzig, 1902, Bd. xl. S. 155.

Gruber . . . . . München. med. Wchnschr., 1899, Bd. xlvi. S. 1329.

HahN und Trommsdorff . Tbid., 1900, Bd. xlvii. S. 413.

Joos . . . . . . . Ztschr. f. Hyg. u. Infectionsterankh., Leipzig, 1901 , Bd. xxxvi. S. 422 ; and 1902, Bd. xl. S. 203.

JATTA . . . . . . Ibid., 1900, Bd. xxxiii. S. 185. 
Madsen and Jörgensen . Festskrift ved Indvielsen af Statens Seruminstitut, 1902, vi.

Kraus . . . . . . . Wien. klin. Welinschr., 1897, Bd. x. S. 736.

Ianmotte ht Bossanrt . Bull. Acad. roy. de méd. de Belg., Bruxelles, 1897 , Sér. 4, tome xi. p. 646.

Lrvin . . . . . . Festskrift ved Indvielsen af Statens Seruminstitut, 1902, vii.

Malvoz . . . . . Ann. de l'Inst. Pasteur, Paris, 1897, tome xi. p. 582.

Nrisser und Frikdrasanx. München. med. Wchnschr., 1904, Bd. li. S. 465, 827.

NhUFrd . . . . . . Ztschr. f. Hyg. u. Infectionskrankh., Leipzig, 1902 , Bd. xl. S. 54.

Nicolle . . . . . Ann. de l'Inst. Pasteur, Paris, 1898, tome xii. p. 161.

Nicolle et Trinet. . . Ibid., 1902, tome xvi. p. 562.

NolF . . . . . . Ibid., 1900, tome xiv. p. 297.

Pick . . . . . . Beitr. z. chem. Phys. u. Path., Braunschweig, 1901, Bd. i.

Radzievsir . . . . . Ztschr. f. Hyg. u. Infectionskrankh., Leipzig, 1900, Bd. xxxiv. S. 369.

Sabrazìs at Brengurs - Compt. rend. Soc. de biol., Paris, 1899, Sér. 11, tome i. p. 930.

SaCquépér . . . . Ann. de l'Inst. Pasteur, Paris, 1901, tome xv. p. 249.

VAN DF VELDE . . . . Bull. Acad. roy. de méd. de Belg., Bruxelles, 1897, Sér. 4, tome xi. p. 278.

W AssermaNN . . . . Ztschr. f. Hyg. u. Infectionskrankh., Leipzig, 1902, Bd. xlii. S. 267. 